\title{
Chemical Energy Storage System for SEGS Solar Thermal Power Plant
}

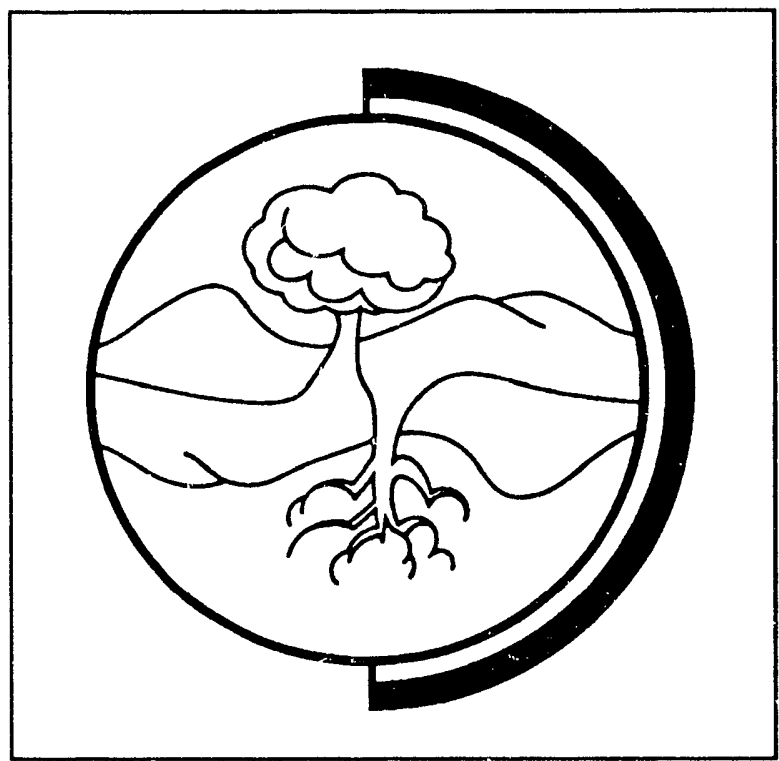

September 1991

Prepared for the U.S. Department of Energy Contract DE-AC06-76RLO 1830

Pacific Northwest Laboratory Operated for the U.S. Department of Energy by Battelle Memorial Institute 


\title{
DISCLAIMER
}

This report was prepared as an account of work sponsored by an agency of the United States Government. Neither the United States Government nor any agency thereof, nor Battelle Memorial Institute, nor any of their employees, makes any warranty, expressed or implied, or assumes any legal liability or responsibility for the accuracy, completeness, or usefulness of any information, apparatus, product, or process disclosed, or represents that its use would not infringe privately owned rights. Reference herein to any specific commercial product, process, or service by trade name, trademark, manufacturer, or otherwise does not necessarily constitute or imply its endorsement, recommendation, or favoring by the United States Government or any agency thereof, or Baltelle Memorial Institute. The views and opinions of authors expressed herein do not necessarily state or reflect those of the United States Government or any agency thereof.

\author{
PACIFIC NORTHWEST LABORATORY \\ operated by \\ BATTELLE MEMORIAL INSTITUTE \\ for the \\ UNITED STATES DEPARTMIENT OF ENERGY \\ under Contract DE-ACO6-76RLO 1830
}

Printed in the United States of America

Available to DOE and DOE contractors from the

Office of Scientific and Technical Information, P.O. Box 62, Oak Ridge, TN 37831; prices available from (615) $576-8401$. FTS $626-8401$.

Available to the public from the National Technical Information Service, U.S. Department of Commerce, 5285 Port Royal Rd., Springfield, VA 22161. 
PNL --7799

DE92 002217

CHEMICAL ENERGY STORAGE SYSTEM

FOR SEGS SOLAR THERMAL POWER PLANT

D. R. Brown

J. L. LaMarche

G. E. Spanner

September 1991

Prepared for

the U.S. Department of Energy

under Contract DE-ACO6-76RLO 1830

Pacific Northwest Laboratory

Richland, Washington 99352 


\section{SUMMARY}

In October 1988, a symposium was held in Helendale, California, to discuss thermal energy storage (TES) concepts applicable to medium-temperature (200 to $400^{\circ} \mathrm{C}$ ) solar thermal electric power plants, in general, and the solar electric generating system (SEGS) plants developed by Luz International, in particular. The symposium identified chemical reaction energy storage based on the reversible reaction between metal oxides and metal hydroxides as a leading candidate for meeting Luz International's cost and performance requirements. Subsequently, the Pacific Northwest Laboratory conducted this study at the request of the U.S. Department of Energy.

Rocky Research of Boulder City, Nevada, although not a participant in the symposium noted above, has been the principal developer and promoter of metal oxide/hydroxide energy storage systems within the United States. Based on their own studies of equilibrium vapor pressure data and heat and mass transfer rates, a calcium oxide/calcium hydroxide system was chosen as the basis for our study. Data provided by Rocky Research was essential to conducting this study.

The principal objectives of this study were to identify the design conditions, requirements, and potential feasibility for a chemical energy storage system applied to a SEGS solar thermal power plant. The feasibility assessment had several key limitations in scope:

1. Calcium oxide/hydroxide was the only reversible reaction considered; other oxide/hydroxide reactions should also be considered.

2. Heat and mass transfer rates and overall chemical reaction rates were not explicitly modeled; adequate reaction rates for charging and discharging storage were assumed to occur as long as positive temperature and pressure driving forces were maintained in the system.

3. A transient analysis was not conducted; no attempt was made to predict changes in the local storage-medium temperature, heat and mass transfer rates, or heat transfer fluid flow rate during the charging or discharging periods. 
4. Although storage system impacts on other solar plant components were considered, the focus of the evaluation was on the storage system; no annual simulation of a solar thermal plant with or without storage was conducted.

The principal conclusion of this study is that chemical reaction energy storage based on the reversible reaction $\mathrm{CaO}+\mathrm{H}_{2} \mathrm{O}=\mathrm{Ca}(\mathrm{OH})_{2}$ could be technically and economically feasible at a SEGS solar thermal power plant. Second-law efficiencies near $80 \%$ and initial costs of about $\$ 45 /$ kWht were predicted for several alternative design configurations incorporating wetcooling. Second-law efficiencies near $85 \%$ would be possible if dry-cooled SEGS plant designs being developed by Luz are implemented. Although the capital cost estimate exceeds Luz International's stated requirement 0 ? $\$ 25 / \mathrm{kWht}$, ancillary subsystems were found to represent less than $20 \%$ of the total system cost and significant cost reductions could be realized through mass production and further optimization of the reactor heat-exchanger system components.

Critical issues affecting the feasibility of the storage concept include the discharge energy source and details of the reactor heat exchanger design (the proprietary property of Rocky Research). Steam condensation energy rejected while charging must be replaced when discharging. The availability of a low-quality energy source, such as low-pressure extraction steam, is required to achieve adequately high second-law efficiency for the storage system. The proprietary design of the chemical reactor subsystem leaves considerable design, cost, and performance uncertainty that remains to be resolved.

Further assessment of chemical energy storage for a SEGS power plant application should investigate the mass transfer, heat transfer, and chemical reaction dynamics of the calcium oxide/hydroxide system to determine the required pressure and temperature gradients for modified reactor designs. Reactor heat-exchanger manufacturing costs need to be estimated for utilityscale storage systems. In addition, the potential benefit of boosting the discharge heat transfer fluid temperature above that normally delivered, thus allowing higher inlet steam temperatures and improved steam cycle conversion efficiency, should be investigated. 
Whether or not this particular reversible reaction proves feasible for application at the SEGS power plants, the general concept has considerable potential for high-temperature energy storage and heat-pump applications. Other reversible oxide/hydroxide reaction pairs should be investigated as possible chemical reaction energy storage media. Other potential applications of oxide/hydroxide energy storage systems should be identified. 


\section{ACKNOWLEDGEMENTS}

The authors would like to thank Dr. Uwe Rockenfeller of Rocky Research and Dr. David Kearney of Luz International for providing essential data regarding the chemical reaction energy storage system and solar thermal power plant, respectively. The advice and support of PNL staff members Kevin Drost, Landis Kannberg, and Sue Arey are also sincerely appreciated. 


\section{CONTENTS}

SUMMARY .............................

ACKNOWLEDGEMENTS ................................. vi

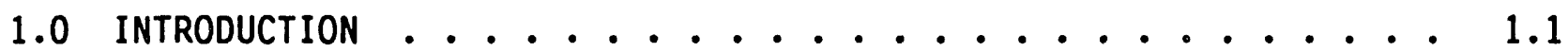

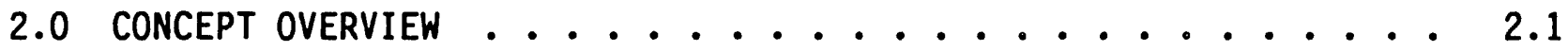

3.0 SYSTEM CONFIGURATION SCREENING ................... 3.1

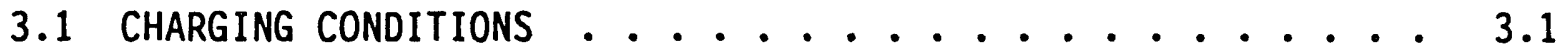

3.2 DISCHARGING CONDITIONS . . . . . . . . . 3.2

4.0 SElECTED CONFIGURATION EVAlUation . . . . . . . . . . 4.1

4.1 DESIGN CONDITIONS $\ldots \ldots \ldots . \ldots . \ldots . \ldots . \ldots$

4.2 DESIGN AND PERFORMANCE ANALYSIS . . . . . . . 4.4

4.2 .1 Cooling Subsystem ............ 4.5

4.2.2 Condensate Subsystem . . . . . . . . 4.7

4.2 .3 HTF Subsystem . . . . . . . . . 4 4.8

4.2.4 Extraction Steam Subsystem . . . . . . 4.8

4.2.5 Chemical Reactor Subsystem . . . . . . . 4.9

4.2.6 Other System Performance Impacts ........ 4.11

4.3 COST ANALYSIS .......................... 4.12

5.0 SYSTEM RESULTS ............................ 5.1

6.0 CONCLUSIONS AND RECOMMENDATIONS .............. 6.1

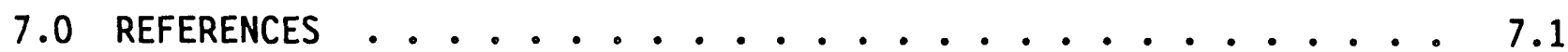


2.1 Reactor Heat Exchanger ... . . . . . . . . . 2.2

2.2 Water Vapor Pressure ............... 2.3

2.3 Generic Storage System ................ 2.4

3.1 Storage Charging Conditions .............. 3.2

3.2 Storage Discharging Conditions ............ 3.3

4.1 Power Plant Schematic Diagram . . . . . . . . . 4.2

4.2 Condensing Conditions ............... 4.3

4.3 Power Plant Plot Plan ............... 4.6

\section{TABLES}

4.1 Cooling Subsystem Design and Performance .......... 4.7

4.2 HTF Subsystem Design and Performance ............ 4.8

4.3 Extraction Steam Subsystem Design and Performance ....... 4.9

4.4 Chemical Reactor Design Factors and Specifications ...... 4.10

4.5 Desuperheating and Condenser Tubing Designs ......... 4.11

4.6 Steam Superheating Losses. . . . . . . . . . . . 4.12

4.7 Cooling Subsystem Costs ................ 4.13

4.8 Condensate Subsystem Costs ............... 4.14

4.9 Extraction Steam Subsystem Costs ............. 4.15

4.10 Chemical Reactor Subsystem Costs ............ 4.15

5.1 System Cost Summary ................. 5.2

5.2 System Parasitic Power Summary ............. 5.3

5.3 Summary of System Characteristics ............. 5.4 


\subsection{INTRODUCTION}

In October 1988, a symposium was held in Helendale, California, to discuss thermal energy storage (TES) concepts applicable to medium-temperature (200 to $400^{\circ} \mathrm{C}$ ) solar thermal electric power plants, in general, and the solar electric generating system (SEGS) plants developed by Luz International, in particular. In addition to Luz, symposium participants included representatives from the Solar Energy Research Institute (SERI), Pacific Northwest Laboratory (PNL), Oak Ridge National Laboratory (ORNL), Argonne National Laboratory (ANL), Institute of Gas Technology (IGT), CBY Associates, University of Houston, Plateforma Solar de Almeria, Dow Chemical, and Ohio State University. Several TES concepts were discussed at the workshop including water vapor/zeolite, phase-change media (PCM) slurry, PCM/heat exchanger, composite PCM, sensible heat/thermocline, and reversible chemical reaction. Of these, chemical reaction energy storage based on the reversible reaction between metal oxides and metal hydroxides was identified as a leading candidate for meeting Luz International's cost and performance requirements. Based on the recommendations of this symposium, the Pacific Northwest Laboratory(a) conducted this study at the request of the U.S. Department of Energy.

Rocky Research of Boulder City, Nevada, although not a participant in the symposium noted above, has been the principal developer and promoter of metal oxide/hydroxide energy storage systems within the United States. Based on their own studies of equilibrium vapor pressure data and heat and mass transfer rates, a calcium oxide/calcium hydroxide system was chosen as the basis for our study. Data provided by Rocky Research was essential to conducting this study.

The principal objectives of this study were to identify the design conditions, requirements, and potential feasibility for a chemical energy

(a) Operated for the U.S. Department of Energy by Battelle Memorial Institute. 
storage system applied to a SEGS solar thermal power plant. The feasibility assessment had several key limitations in scope:

1. Calcium oxide/hydroxide was the only reversible reaction considered; other oxide/hydroxide reactions should also be considered.

2. Heat and mass transfer rates and overall chemical reaction rates were not explicitly modeled; adequate reaction rates for charging and discharging storage were assumed to occur as long as positive temperature and pressure driving forces were maintained in the system.

3. A transient analysis was not conducted; no attempt was made to predict changes in the local storage-medium temperature, heat and mass transfer rates, or heat transfer fluid flow rate during the charging or discharging periods.

4. Although storage system impacts on other solar plant components were considered, the focus of the evaluation was on the storage system; no annual simulation of a solar thermal plant with or without storage was conducted.

The remaining sections of this report begin by providing an overview of the chemical reaction energy storage concept and a SEGS solar thermal power plant. Subsequent sections describe the initial screening of alternative evaporation energy sources and the more detailed evaluation of design alternatives considered for the preferred evaporation energy source. The final sections summarize the results, conclusions, and recommendations. 


\subsection{CONCEPT OVERVIEW}

Since 1984, Luz International Ltd. has installed and operated several solar electric generating systems (SEGS) in Southern California. Parabolic trough collectors are used to heat a synthetic heat transfer fluid, which in turn is used to generate steam and drive a conventional steam Rankine conversion cycle engine. As of October 1990, the combined generating capacity of the SEGS power plants was approximately $350 \mathrm{MW}$. An additional $320 \mathrm{MW}$ (at $80 \mathrm{MW}$ per plant) was also under construction or being planned at that time.

In general, energy storage could provide several useful services in a SEGS plant by decoupling thermal energy collection from electric power generation. Relatively small storage systems could be used to smooth out the dynamic impact of cloud transients on solar energy collection. Larger storage systems could be used to allow power production late into trie evening after the sun sets. Perhaps most importantly, energy storage would allow a larger fraction of a plant's electric power generation to occur during the utility's peak demand period(s), resulting in increased revenues.

The energy storage system evaluated in this study was designed to significantly extend plant operating hours by providing 4 additional hours of generating capacity at the plant's rated capacity of $80 \mathrm{MW}$. Allowing for $7 \mathrm{MW}$ of plant parasitic power requirements and a thermal-to-electric conversion efficiency of 0.376 , the net thermal capacity of the storage system was 925 MWht. Storage charging was to occur over an 8-hour pericd during the day.

Of course, the potential benefits of incorporating energy storage in a power plant must be compared to the costs. Previous analyses conducted by Luz have indicated that the initial capital cost of an energy storage system would have to about $\$ 25 / \mathrm{kWht}$ of thermal capacity or less to be economically attractive (Luz International 1989). The expected costs of most, if not all. of the energy storage technologies considered at the 1988 symposium exceed this limit. This includes using the synthetic heat transfer fluid in a onetank or two-tank sensible heat storage system. 
The chemical reaction energy storage system considereo is based on the reversible reaction, $\mathrm{CaO}+\mathrm{H}_{2} \mathrm{O}=\mathrm{Ca}(\mathrm{OH})_{2}$. During the charging process, thermal energy drives an endothermic reaction creating calcium oxide and water from calcium hydroxide. The reverse occurs on discharge when calcium oxide and water combine in an exothermic reaction to produce calcium hydroxide and release thermal energy.

The concept is illustrated in Figure 2.1. Hot heat transfer fluid (HTF) from the solar collector field enters a reactor heat exchanger, which holds the calcium oxide/calcium hydroxide storage medium. (Heat exchanger design details are the propiriatary property of Rocky Research.) Energy transferred from the HTF to the storage medium dirives the endothermic charging reaction as described above. The principal reaction driving force is the difference between the vapor pressure if water over the calcium oxide/calcium hydroxide storage medium. and the bulk water vapor pressure. The overall reaction rate is controlled

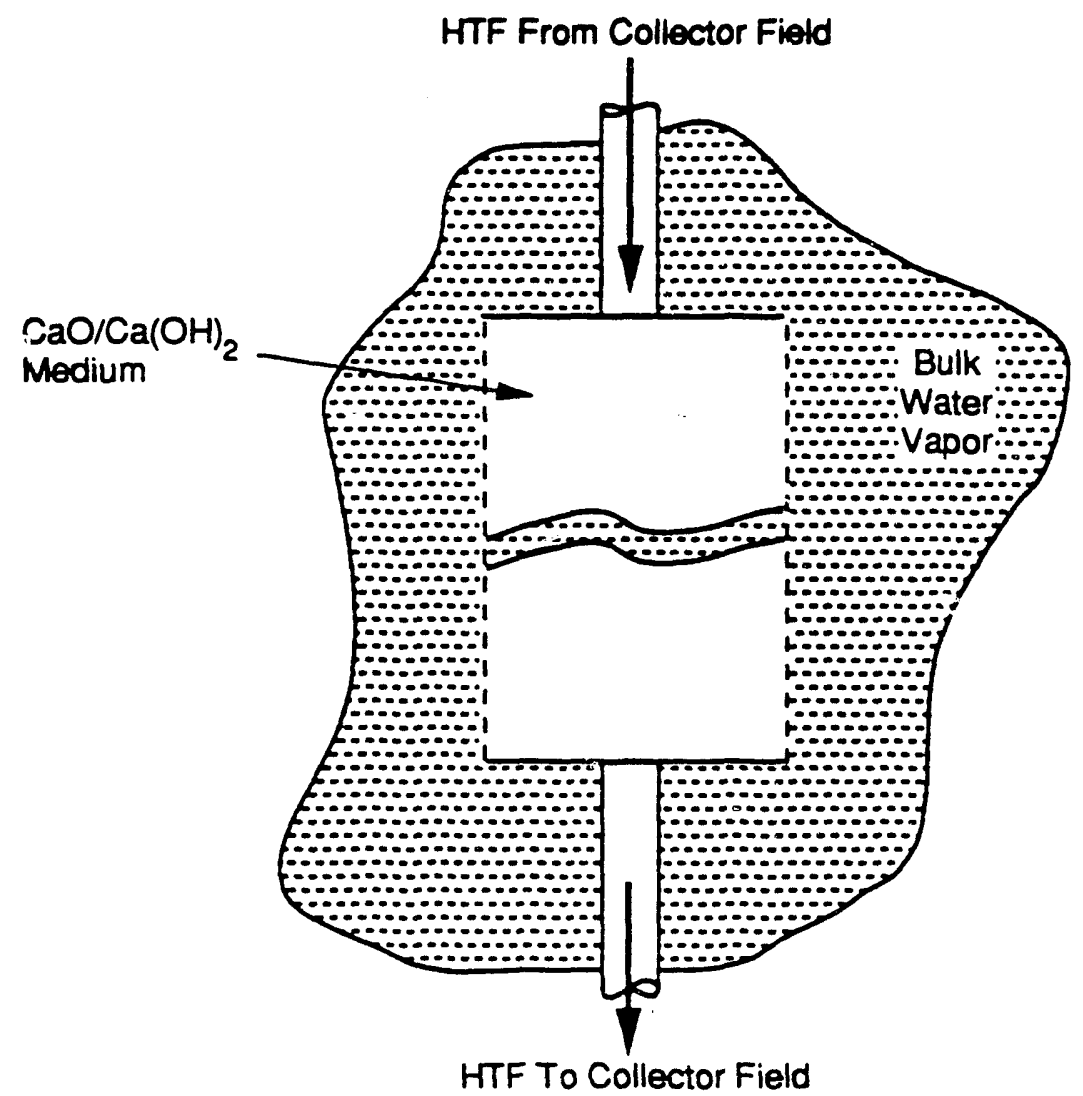

FIGURE 2.1. Reactor Heat Exchánger 
by the rate of heat and mass transfer through the storage medium as well as basic reaction kinetics. Concept testing of this process has beer, completed by Rocky Research.

Large differences between the vapor pressure of water over the calcium. oxide/calcium hydroxide storage medium and the vapor pressure of pure water provides the basis for constructing an energy storage system based on this reaction. Vapor pressures for pure water and the storage medium $\left[\mathrm{CaO} / \mathrm{Ca}(\mathrm{OH})_{2}\right.$ matrix] are presented in Figure 2.2. As shown in Figure 2.2, the charging reaction will occur as long as the water vapor pressure over the storage medium exceeds the bulk water vapor pressure. Discharge of the system will occur when the pressure gradient is reversed. The prircipal attraction of this concept is that once the system is charged, relatively low-temperature bulk water vapor can provide the pressure differential required to discharge the system and release thermal energy at a much higher temperature. (In fact,

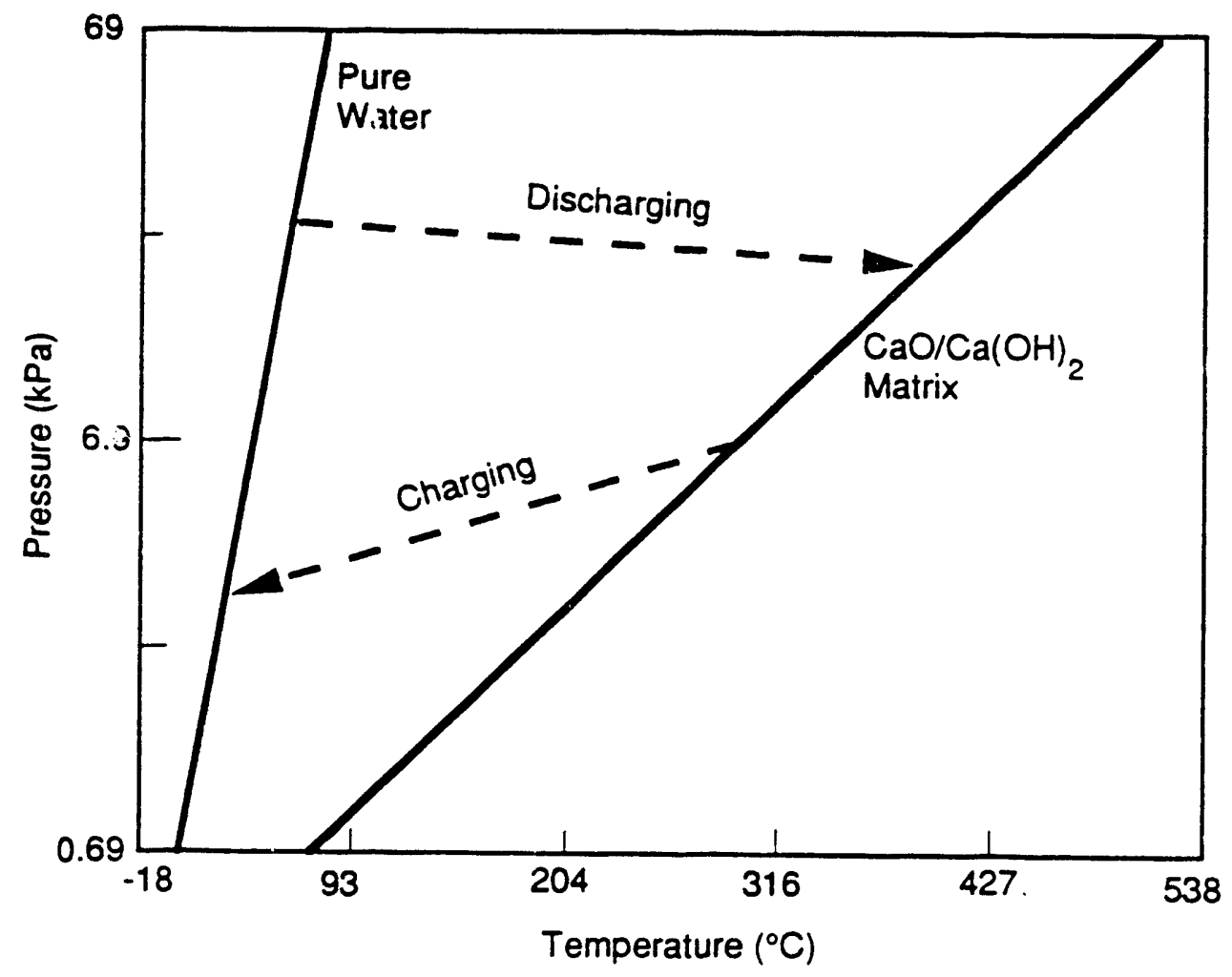

FIGURE 2.2. Water Vapor Pressure 
the bulk water vapor temperature could easily be warm enough to allow the HTF discharge temperature to exceed the HTF charging temperature.)(a)

A simplified diagram of a generic oxide/hydroxide chemical react on energy storage system is shown in Figure 2.3. During the charging mode superheated water vapor migrates to the edge of the reactor storage mediun. where it is desuperheated, and then condensed at the bulk water vapor temperature and pressure created by the cooling water. In actual practice, desuperheating and condensing tubing might be integrated with the storage medium in the reactor vessel. Otherwise, extremely large-diameter ducting would be required to transport the low-pressure, superheated steam to a separate desuperheating and condensing unit. The condensate is then pumped to a storage tank.

During the discharging mode, condensate is pumped from the storage tank, evaporated using one of several alternative energy sources, and then is returned to the reactor where it migrates into the storage medium.

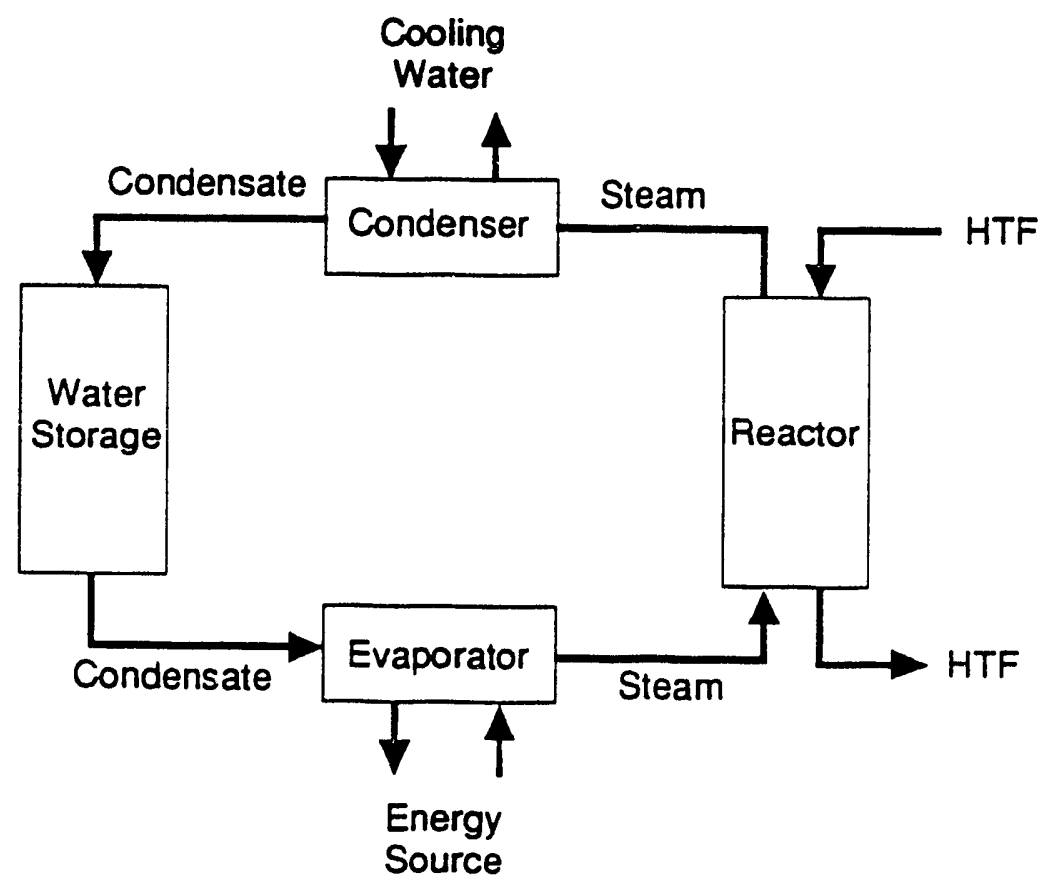

FIGURE 2.3. Generic Storage System

(a) Conceptualization of the process and first reduction to practice was performed by Rocky Research, Boulder City, Nevada; related patents are pending. 2.4 
Considerable energy is rejected to the cooling water to desuperheat and condense the steam leaving the reactor storage medium during the cilarging mode and must be replaced during discharge. The discharge energy source is criticai to the feasibility of the concept. Five alternative energy sources were considered in the system configuration screening analysis, described in the following section. 


\subsection{SYSTEM CONFIGURATION SCREENING}

An initial screening evaluation was conducted to determine if the chemical reaction energy storage system was technically feasible, given the SEGS power plant design requirements. Required design conditions were established through review of various publications prepared by Luz, as well as by direct consultation with Luz representatives. The evaluation focused specifically on the temperature and pressure driving forces that are likely to be available during charge and discharge and the approximate storage system efficiencies that would result.

\subsection{CHARGING CONDITIONS}

Storage charging conditions are shown in Figure 3.1. The design HTF · temperature from the solar collector field is $391^{\circ} \mathrm{C}\left(735^{\circ} \mathrm{F}\right)$. The normal return temperature to the field is $304^{\circ} \mathrm{C}\left(579^{\circ} \mathrm{F}\right)$, but it is allowed to be as high as $315^{\circ} \mathrm{C}\left(599^{\circ} \mathrm{F}\right)$. The HTF return temperature is a critical design condition because it establishes the reaction rate limiting conditions in the storage system while charging. A higher HTF return temperature is desirable for the storage system because it increases the allowable storage-medium temperature, hence increasing the available vapor pressure driving force. However, increasing the HTF return temperature to the field increases the overall HTF flow rate per MWt, which adversely affects the collector field design and performance and must be considered in the overall analysis of the storage system. The storage medium must be cooler than the HTF, so that heat will transfer into the storage medium from the HTF. An $11^{\circ} \mathrm{C}\left(20^{\circ} \mathrm{F}\right)$ temperature difference was assumed between the exiting HTF and the storage medium, resulting in a storage-medium temperature of $304^{\circ} \mathrm{C}\left(579^{\circ} \mathrm{F}\right)$ at this "pinchpoint." This assumption was based on the results of a preliminary experimental test.performed by Rocky Research in 1988.

At a temperature of $304^{\circ} \mathrm{C}\left(579^{\circ} \mathrm{F}\right)$, the water vapor pressure over the storage medium is $7.03 \mathrm{kPa}(1.02 \mathrm{psia})$. The bulk water vapor pressure must be lower than $7.03 \mathrm{kPa}$ (1.02 psia) for the charging reaction to be possible at this storage-medium temperature. This corresponds to a water vapor temperature 


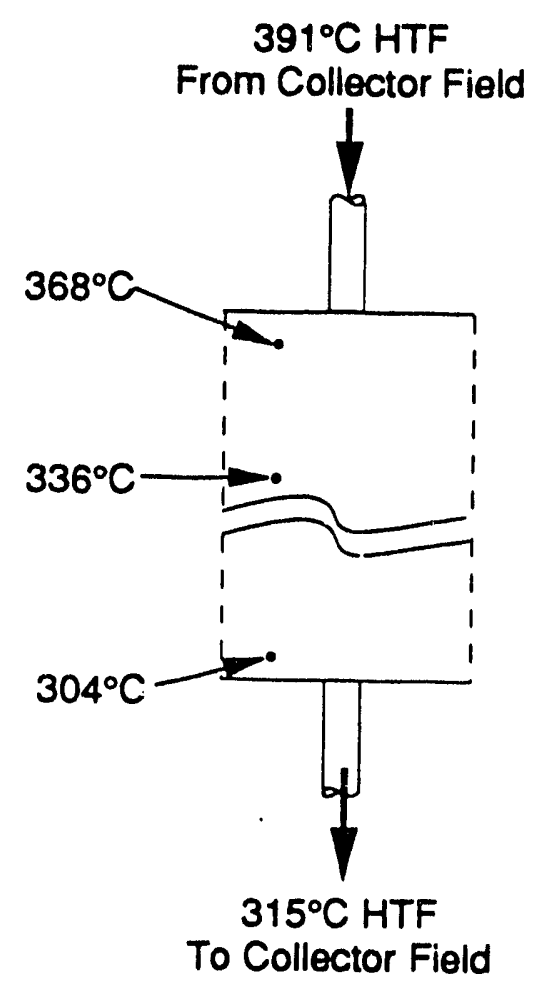

\section{FIGURE 3.1. Storage Charging Conditions}

of $39^{\circ} \mathrm{C}\left(102^{\circ} \mathrm{F}\right)$. Mechanical draft evaporative cooling towers supply $26^{\circ} \mathrm{C}$ $\left(78^{\circ} \mathrm{F}\right)$ cooling water at a SEGS plant. Therefore, a bulk water vapor pressure as low as $3.24 \mathrm{kPa}(0.47 \mathrm{psia})$ could be maintained in theory, although practical cooling water flow rates and condenser approach temperatures raise this value somewhat. Thus, storage system charging was found to be possible for the SEGS design conditions, but would require a relatively low cooling water/bulk water vapor approach temperature. Determining whether or not the specific temperature and vapor pressure driving forces available would result in an adequately quick reaction rate was beyond the scope of this analysis.

\subsection{DISCHARGING CONDITIONS}

Storage discharging conditions are shown in figure 3.2. The minimum HTF temperature discharged to the steam generator is $350^{\circ} \mathrm{C}\left(662^{\circ} \mathrm{F}\right)$. The corresponding HTF temperature returning to the storage system from the steam 


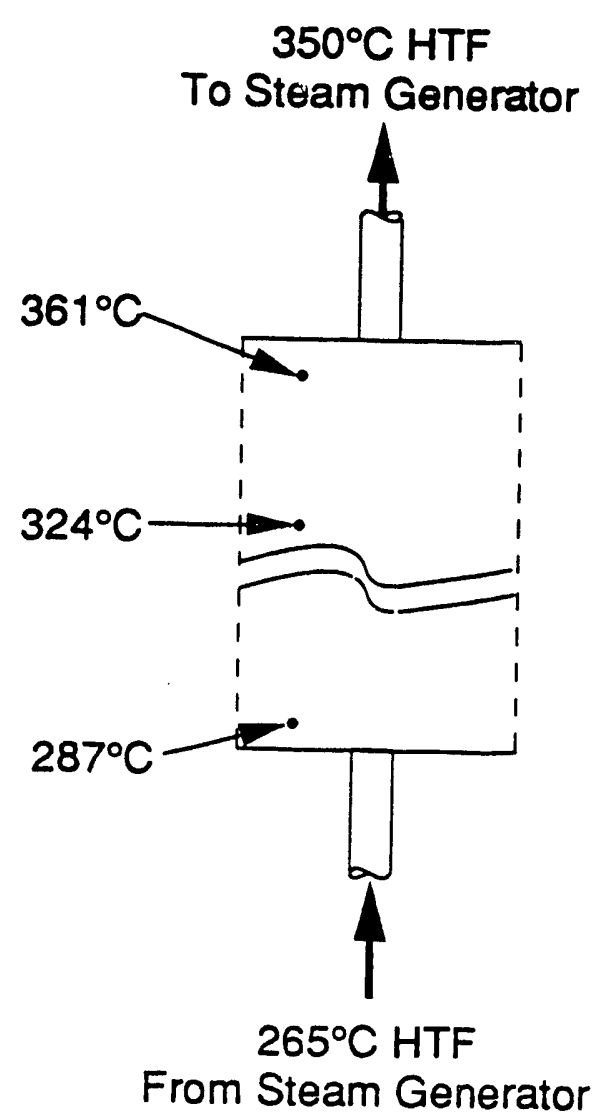

Case 1

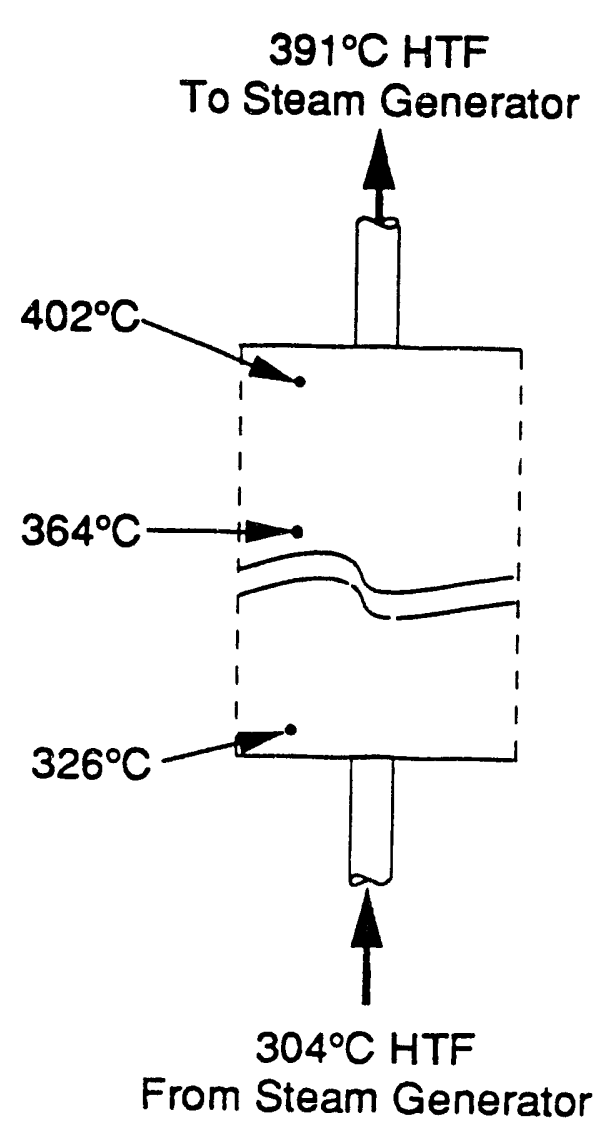

Case 2

\section{FIGURE 3.2. Storage Discharging Conditions}

generator is $265^{\circ} \mathrm{C}\left(509^{\circ} \mathrm{F}\right)$. The HTF discharge temperature is a critical design condition because it establishes the reaction rate limiting conditions in the storage system while discharging. A lower HTF discharge temperature is desirable for the storage system because it decreases the allowable storagemedium temperature, hence increasing the available vapor pressure driving force. However, lowering the HTF discharge temperature lowers the steam turbine inlet temperature, which adversely affects the plant efficiency and must be considered in the overall analysis of the storage system. The storage 
medium must be warmer than the HTF, so that heat will transfer from the storage medium into the HTF. An $11^{\circ} \mathrm{C}\left(20^{\circ} \mathrm{F}\right)$ temperature difference was allowed between the exiting HTF and the storage medium, resulting in a storage-medium temperature of $361^{\circ} \mathrm{C}\left(682^{\circ} \mathrm{F}\right)$ at this "pinch-point."

At a temperature of $361^{\circ} \mathrm{C}\left(682^{\circ} \mathrm{F}\right)$, the water vapor pressure over the storage medium is $12.8 \mathrm{kPa}(1.85 \mathrm{psia})$. The bulk water vapor pressure must be greater than $12.8 \mathrm{kPa}$ ( $1.85 \mathrm{psia})$ for the discharging reaction to be possible at this storage-medium temperature. This pressure corresponds to a water vapor temperature of $51^{\circ} \mathrm{C}\left(123^{\circ} \mathrm{F}\right)$. Water vapor condensed during the charging cycle must be vaporized and superheated to the storage-medium discharge temperature. If possible, it would be desirable to use relatively low-grade, low-value energy sources to provide this energy. "The following five alternatives were considered: 1) turbine condenser cooling water, 2) turbine extraction steam, 3) HTF returning from the steam generator, 4) heat of reaction energy, and 5) natural gas.

For a SEGS power plant, cooling water exits the steam turbine condenser at $36^{\circ} \mathrm{C}\left(96^{\circ} \mathrm{F}\right)$. Unfortunately, this temperature is considerably less than the minimum bulk water vapor temperature of $51^{\circ} \mathrm{C}\left(123^{\circ} \mathrm{F}\right)$. Thus, steam turbine condenser cooling water is infeasible as an evaporation energy source.

Under normal design conditions, steam is expanded to $7.03 \mathrm{kPa}$ ( $1.02 \mathrm{psia}$ ) in the turbine before being condensed. Higher pressure extraction steam could be sent directly to the reactor to discharge the storage system. Make-up boiler feedwater would be supplied from condensate collected during the storage charging cycle. This energy source has the advantage of being able to meet any reasonable bulk water vapor pressure requirement associated with alternative HTF discharge temperatures and is lower in quality (availability) than alternatives 3 through 5 . The obvious disadvantage is that steam extraction reduces the energy conversion efficiency of the steam cycle.

Determining the minimum vapor pressure driving force that would result in an adequately quick reaction rate was beyond the scope of this anaiysis. For consistency, the minimum discharge vapor pressure driving force was assumed to be roughly twice that required for charging because the thermal discharge rate 
is twice the charge rate. Allowing for frictional losses, steam would have to be extracted at about $20.7 \mathrm{kPa}$ ( 3 psia). Extracting steam at this pressure and the flow rate required results in a $6 \%$ loss in generating capacity.

In addition to extraction steam losses, electric generating capability is lost in the reactor because part of the heat of reaction energy liberated is used to superheat the saturated vapor at $20.7 \mathrm{kPa}(3 \mathrm{psia})\left[61^{\circ} \mathrm{C}\left(141^{\circ} \mathrm{F}\right)\right]$ to the average storage-medium temperature $\left[324^{\circ} \mathrm{C}\left(616^{\circ} \mathrm{F}\right)\right.$ or $\left.364^{\circ} \mathrm{C}\left(687^{\circ} \mathrm{F}\right)\right]$. Approximately $9 \%$ of the reaction energy is used for superheating. Thus, $15 \%$ of the electric generating potencial stored is lost using steam extraction as the vaporization energy source.

Using either HTF returning from the steam generator or the heat of reaction energy has the advantage of being able to meet any reasonable vapor pressure requirement associated with alternative HTF discharge temperatures and does not adversely impact the steam turbine cycle. However, both energy sources consume a much higher quality energy form and suffer a greater overall loss in electric generating capacity. Boiling and superheating bulk water vapor for discharge would consume about half of the heat of reaction energy available if this were the only energy source used. Vaporizing the water with HTF returning to the reactor from the steam generator would also consume about half of the heat of reaction energy because any energy extracted from the HTF prior to entering the reactor must be replaced by heat of reaction energy.

Finally, natural gas could be used to generate superheated steam for discharging the storage system. Natural gas is currently used to fire HTF heaters at the SEGS plants to ensure that power is generated during peak demand periods and to extend operating hours and generally improve plant operating stability. However, using natural gas to generate low-pressure steam for storage discharge would be less efficient than using extraction steam. In addition, the SEGS plants are strictly regulated by the Federal Energy Regulatory Commission on the amount of natural gas that can be burned.

of the five vaporization and superheating energy sources considered, using turbine condenser cooling water was found to be technically infeasible. 
of the remaining options, turbine extraction steam (in combination with heat of reaction energy) was found to offer superior energy efficiency and was selected as the basis for the more detailed system configuration evaluations. 


\subsection{SELECTED CONFIGURATION EVALUATION}

A schematic diagram of the selected energy storage system and power plant configuration is shown in Figure 4.1. Several alternative design conditions were considered to identify cost and performance tradeoffs and important design factors affecting the feasibility of the concept. The alternative design conditions evaluated are presented first, followed by descriptions of the design, performance, and cost analyses. Cost and performance results are summarized in the section that follows.

\subsection{DESIGN CONDITIONS}

Heat transfer fluid and storage-medium temperature conditions during charging were shown in Figure 3.1. The HTF enters the reactor from the solar field at $391^{\circ} \mathrm{C}\left(735^{\circ} \mathrm{F}\right)$ and leaves at $315^{\circ} \mathrm{C}\left(599^{\circ} \mathrm{F}\right)$. The approach temperature at the HTF outlet was set at $11^{\circ} \mathrm{C}\left(20^{\circ} \mathrm{F}\right)$, yielding a storage-medium temperature of $304^{\circ} \mathrm{C}\left(579^{\circ} \mathrm{F}\right)$ at this point. The approach temperature at the HTF inlet was assumed to be $22^{\circ} \mathrm{C}\left(40^{\circ} \mathrm{F}\right)$. Logic dictates that it should he higher than the exit approach temperature. The storage medium will be warmest near the HTF inlet. This produces a higher water vapor pressure driving force, hence a higher mass transfer driving force, which promotes a more rapid reaction rate. A higher reaction rate requires an increase in the heat transfer rate as well as mass transfer rate, thus requiring a larger temperature difference. An average storage-medium temperature of $336^{\circ} \mathrm{C}$ $\left(637^{\circ} \mathrm{F}\right)$ was calculated based on the two storage-medium end-point conditions.

Superheated vapor leaving the storage medium [(at an average temperature of $\left.336^{\circ} \mathrm{C}\left(637^{\circ} \mathrm{F}\right)\right]$ is condensed at a temperature lower than $39^{\circ} \mathrm{C}\left(102^{\circ} \mathrm{F}\right)$ to maintain a positive vapor pressure driving force between the storage medium and the bulk conditions. The minimum vapor pressure differential required to charge the reactor was not evaluated in this study. Nevertheless, two alternative condensate temperatures (and corresponding vapor pressures) were investigated to determine the impact on the cooling system. Key fluid temperatures are shown in Figure 4.2 . Superheated vapor at $336^{\circ} \mathrm{C}\left(637^{\circ} \mathrm{F}\right)$ is 


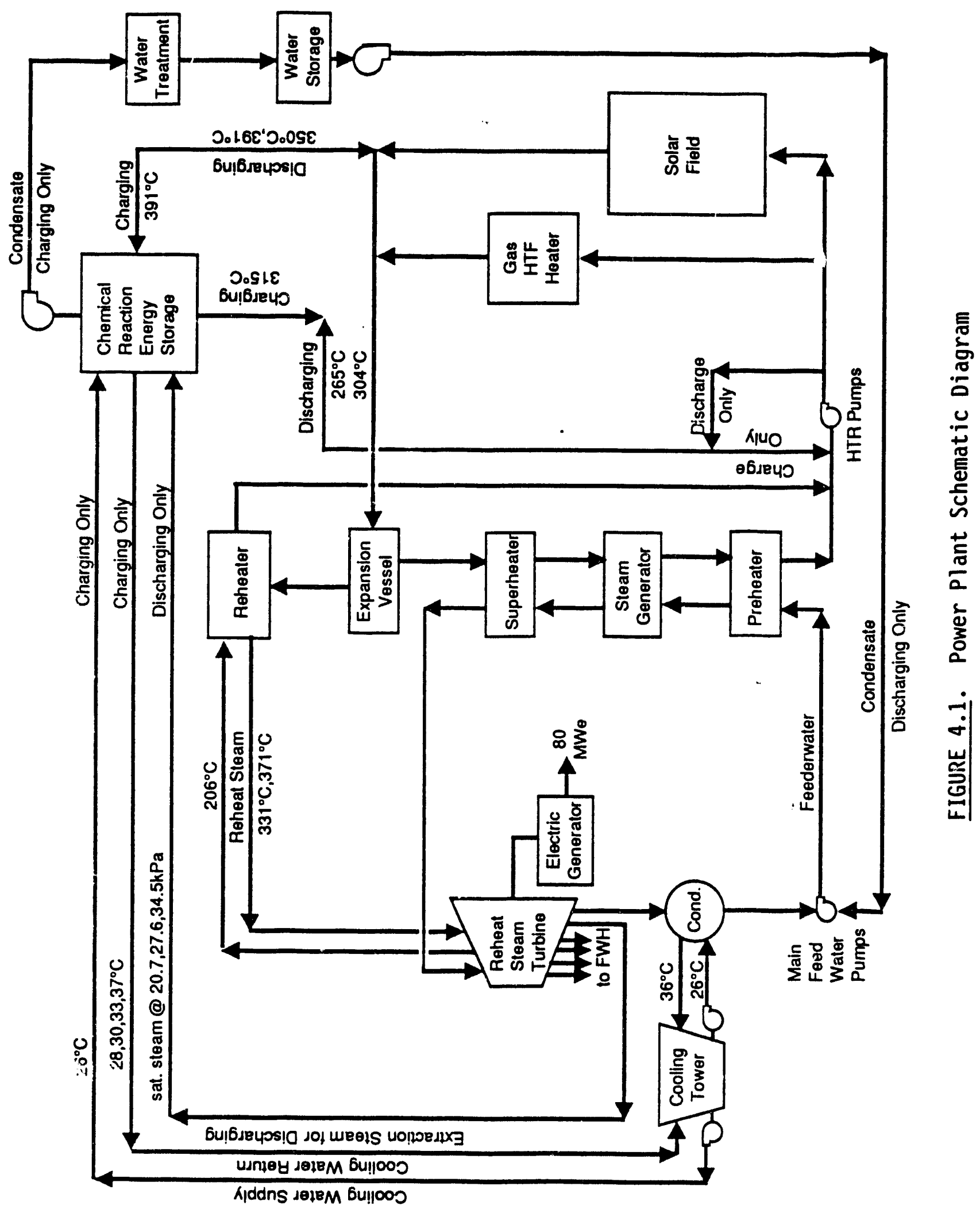

4.2 


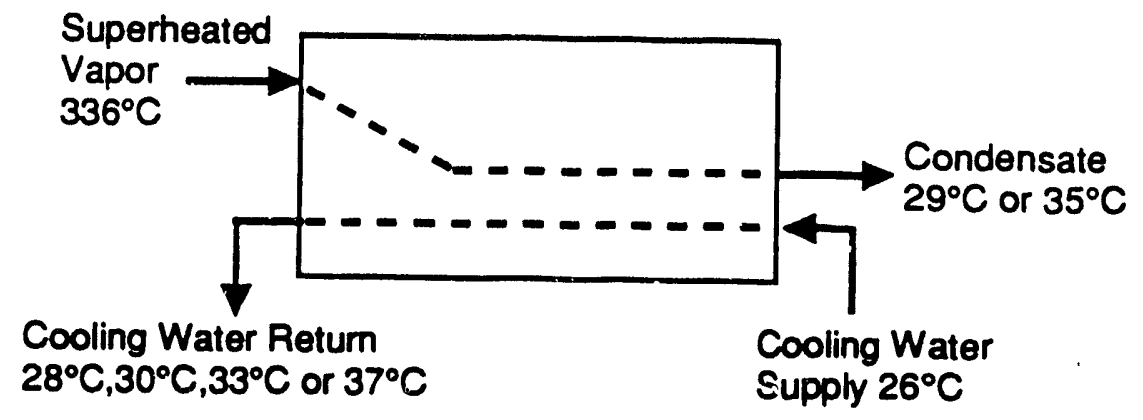

FIGURE 4.2. Condensing Conditions

cooled and condensed at either $29^{\circ} \mathrm{C}\left(85^{\circ} \mathrm{F}\right)$ or $35^{\circ} \mathrm{C}\left(95^{\circ} \mathrm{F}\right)$. At the $304^{\circ} \mathrm{C}$ $\left(579^{\circ} \mathrm{F}\right)$ reactor storage-medium pinch-point, the vapor pressure of water over the storage medium is $7.03 \mathrm{kPa}(1.02 \mathrm{psia})$. Wacer vapor pressures over pure water at $29^{\circ} \mathrm{C}\left(85^{\circ} \mathrm{F}\right)$ and $35^{\circ} \mathrm{C}\left(95^{\circ} \mathrm{F}\right)$ are $4.14 \mathrm{kPa}(0.60 \mathrm{psia})$ and $5.65 \mathrm{kPa}$ (0.82 psia), respectively. Thus, the two condensation temperatures correspond to vapor pressure driving forces of $2.90 \mathrm{kPa}(0.42 \mathrm{psia})$ and $1.38 \mathrm{kPa}(0.20$ psia).

Cooling water is supplied at $26^{\circ} \mathrm{C}\left(78^{\circ} \mathrm{F}\right)$ from the cooling tower and returns to the cooling tower at either $28^{\circ} \mathrm{C}\left(82^{\circ} \mathrm{F}\right)$ or $30^{\circ} \mathrm{C}\left(86^{\circ} \mathrm{F}\right)$ for an $29^{\circ} \mathrm{C}$ $\left(85^{\circ} \mathrm{F}\right)$ condensing temperature. Cooling water return temperatures of $33^{\circ} \mathrm{C}$ $\left(92^{\circ} \mathrm{F}\right)$ and $37^{\circ} \mathrm{C}\left(98^{\circ} \mathrm{F}\right)$ were considered for the $35^{\circ} \mathrm{C}\left(95^{\circ} \mathrm{F}\right)$ condensate temperature. The alternative cooling water return temperatures and condensate temperatures allowed an investigation of the cost and performance impacts of the cooling tower, cooling water loop, and desuperheater/condenser.

Two sets of discharging conditions were considered and were shown in Figure 3.2. Discharging storage with HTF entering at $304^{\circ} \mathrm{C}\left(579^{\circ} \mathrm{F}\right)$ and exiting at $391^{\circ} \mathrm{C}\left(735^{\circ} \mathrm{F}\right)$ exactly matches the standard supply and return temperatures for a SEGS solar collector field, allowing production of their standard steam conditions. Alternatively, entering and exiting HTF temperatures of $265^{\circ} \mathrm{C}$ $\left(509^{\circ} \mathrm{F}\right)$ and $350^{\circ} \mathrm{C}\left(662^{\circ} \mathrm{F}\right)$, respectively, were considered, corresponding to design conditions evaluated by Luz for other storage systems. Inlet, exit, and average storage-medium temperatures were established using the same logic described above for the charging conditions. 
The lower HTF discharge temperatures have the disadvantage of producing lower temperature steam, with a resulting lower steam cycle conversion efficiency. However, the water vapor pressure over the storage medium at the pinch-point $\left[361^{\circ} \mathrm{C}\left(682^{\circ} \mathrm{F}\right)\right]$ is only $12.8 \mathrm{kPa}(1.85 \mathrm{psia})$ compared to $19.7 \mathrm{kPa}$ $(2.85 \mathrm{psia})$ at the $402^{\circ} \mathrm{C}\left(755^{\circ} \mathrm{F}\right)$ pinch-point for the higher HTF discharge temperature conditions. Thus, steam to discharge the storage system can be extracted from the turbine at a lower pressure, which has a positive impact on turbine cycle efficiency.

Three alternative steam extraction pressures were considered: 20.7, 27.6 and $34.5 \mathrm{kPa}(3,4$, and $5 \mathrm{psia})$. Steam must be extracted at an adequate pressure to allow for frictional losses in transit from the turbine to the reactor and to have an adequate vapor pressure driving force between the bulk conditions and the storage medium at the pinch-point. The vapor pressure driving force required on discharge is likely to be double that required on charge because the discharge rate is double the charge rate. Steam extraction pressures of 20.7 and $27.6 \mathrm{kPa}$ ( 3 and 4 psia) were considered reasonable for the lower HTF discharge temperature case; 27.6 and $34.5 \mathrm{kPa}$ (4 and $5 \mathrm{psia}$ ) extraction steam was coupled with the higher HTF discharge temperature case.

In summary, the following alternative design conditions were evaluated: two vapor condensation temperatures and four cooling water return temperatures on charge, and two HTF exit temperatures and three steam extraction temperatures on discharge.

\subsection{DESIGN AND PERFORMANCE ANALYSIS}

The design analysis was structured to provide an adequate characterization of energy storage system component cost and performance. Major subsystems are cooling, condensate, HTF, extraction steam, and the chemical reactor. Individual components of each subsystem are listed below:

- Cooling subsystem: cooling tower, cooling water piping and pumps

- Condensate subsystem: condensate piping and pumps, storage, treatment

- HTF subsystem: HTF piping 
- Extraction steam subsystem: extraction steam piping

- Chemical reactor subsystem: reactor heat exchanger, desuperheating and condenser tubing, reactor vessel.

The first step in the analysis was to prepare a plot plan (Figure 4.3) showing how the chemical reaction energy storage system could be integrated into the power block of a SEGS solar thermal power plant. A current scale drawing of the power block was reviewed and logical storage system equipment locations and piping pathways were identified. The plot plan was directly used to determine the lengths of various piping added to integrate the storage system. Pipe diameters were set based on engineering rules-of-thumb specifying appropriate design velocities for water, steam, and HTF (Crane 1979). Head loss calculations included the impact of straight-run pipe, bends, fittings, valves, elevation gain, and process equipmenc. Insulation thickness was based on engineering rules-of-thumb specified in Perry and Green (1984).

\subsubsection{Cooling Subsystem}

The cooling subsystem supplies chilled water to the chemical reactor subsystem to condense bulk water vapor that has left the storage medium during the charging cycle. A cooling load of $63 \mathrm{MWt}(215 \mathrm{MMBtu} / \mathrm{hr}$ ) was calculated from the storage charging rate and associated condensation rate and desuperheating and condensing energies. Included in the charging rate was an allowance for the heat of reaction energy used to superheat the extraction steam on discharge. Cooling water is supplied to the condenser tubing at $26^{\circ} \mathrm{C}\left(78^{\circ} \mathrm{F}\right)$ and returns to the cooling tower at either $28^{\circ} \mathrm{C}\left(82^{\circ} \mathrm{F}\right), 30^{\circ} \mathrm{C}$ $\left(86^{\circ} \mathrm{F}\right), 33^{\circ} \mathrm{C}\left(92^{\circ} \mathrm{F}\right)$, or $37^{\circ} \mathrm{C}\left(98^{\circ} \mathrm{F}\right)$. The cooling tower approach temperature was $3.3^{\circ} \mathrm{C}\left(6^{\circ} \mathrm{F}\right)$ in all four cases. Cooling tower design and performance specifications were developed using procedures outlined in Perry and Green (1984).

Other cooling subsystem design and performance characteristics are summarized in Table 4.1. As would be expected, increasing the cooling water return temperature reduces the flow rate, pipe diameter, cooling tower fan power, and cooling water pump power. Pump power does not decrease significantly because head loss through cooling loop equipment is expected to increase with increasing cooling water range (the difference between cooling water return and supply temperatures). 


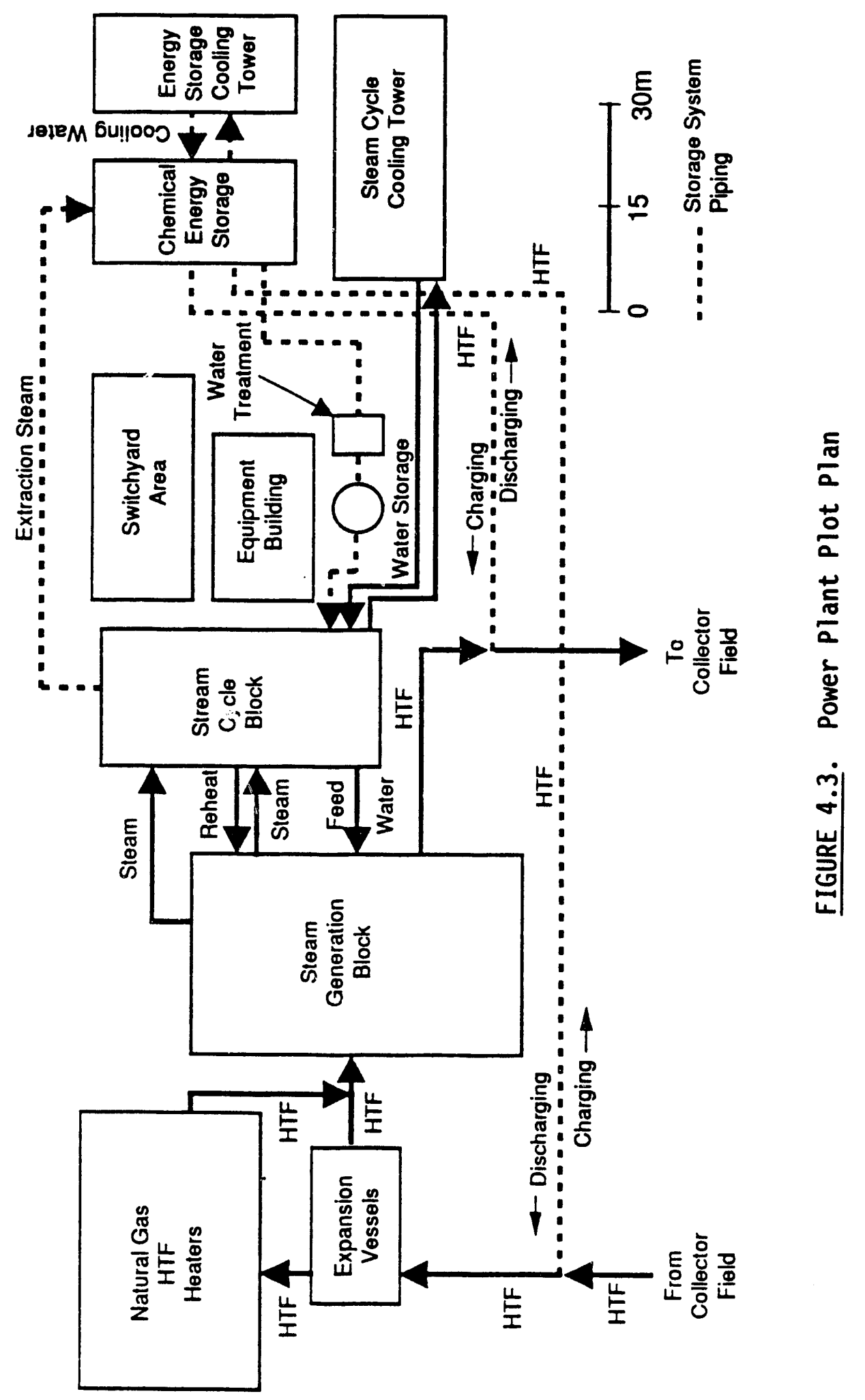

4.6 
TABLE 4.1. Cooling Subsystem Design and Performance

\begin{tabular}{|c|c|c|c|c|}
\hline $\begin{array}{c}\text { Return } \\
\text { Temperature, } \\
{ }^{\circ} \mathrm{C}\left({ }^{\circ} \mathrm{F}\right) \\
\end{array}$ & $\begin{array}{r}\text { Flow Rate, } \\
\mathrm{m}^{3 / \mathrm{min}}(\mathrm{kgpm})\end{array}$ & $\begin{array}{c}\text { Pipe } \\
\text { Diameter, } \\
m \quad(f t) \\
\end{array}$ & $\begin{array}{l}\text { Fan Power, } \\
\mathrm{kW}\end{array}$ & $\begin{array}{c}\text { Pump Power, } \\
\mathrm{kW}\end{array}$ \\
\hline $28(82)$ & 408 (108) & $1.7(5.5)$ & 860 & 1010 \\
\hline $30(86)$ & $204(54)$ & $1.2(3.9)$ & 530 & 890 \\
\hline $33(92)$ & $117(31)$ & $0.9(3.0)$ & 410 & 840 \\
\hline 37 (98) & 79 (21) & $0.8(2.5)$ & 370 & 820 \\
\hline
\end{tabular}

\subsubsection{Condensate Subsystem}

The condensate subsystem collects bulk water vapor condensing in the reactor subsystem during the charcing cycle and transports it to a water treatment unit and subsequently to a storage tank. During the discharge cycle, condensate is pumped from the storage tank to the turbine feedwater loop, replacing extraction steam that is routed to the reactor subsystem.

A thorough investigation of water chemistry will be necessary to determine the compatibility of reactor subsystem condensate with boiler feedwater and the specific water treatment required. If the two streams are incompatible and treatment is ineffective or too costly, the altericive would be to add a heat exchanger to the subsystem to allow heat transfer while keeping the two streams isolated.

Condensate subsystem design and performance characteristics are summarized below.

- Charging line: $1.26 \mathrm{~m}^{3} / \mathrm{min}, 0.10-\mathrm{m}$ pipe, $6 \mathrm{~kW}$ pump

- Discharging line: $2.51 \mathrm{~m}^{3} / \mathrm{min}, 0.12-\mathrm{m}$ pipe, $2 \mathrm{~kW}$ pump

- Storage tank: $718 \mathrm{~m}^{3}$

In general, the flow rates, pipe sizes, and pumping power are trivial compared to the cooling subsystem. Note that although the discharging flow rate is twice the charging flow rate, more pumping power is required for the charging line to cover the head loss through the water treatment unit and elevation gain into the storage tank. 


\subsubsection{HTF Subsystem}

The HTF subsystem consists of the supply and return piping required to connect the collector field main with the chemical reactor subsystem during charging and to connect the steam generator with the chemical reactor subsystem during discharging. The same pipe is used for both charging and discharging; pipe diameters were set to meet the larger discharge flow rate.

HTF subsystem design and performance characteristics are summarized in Table 4.2. Pipe sizes, HTF flow rates, and pumping power were evaluated for HTF discharge temperatures of $391^{\circ} \mathrm{C}\left(735^{\circ} \mathrm{F}\right)$ and $350^{\circ} \mathrm{C}\left(662^{\circ} \mathrm{F}\right)$. Small differences in HTF temperature range and heat capacity over the temperature range cause the mass flow rate, hence pumping power, to be slightly higher for the $350^{\circ} \mathrm{C}\left(662^{\circ} \mathrm{F}\right) \mathrm{HTF}$ discharge temperature case. No additional pumping energy should be consumed during charging compared to operating the reference solar thermal plant without storage. HTF head losses through the chemical reactor are similar to head losses otherwise incurred while passing through the steam generator loop. Head losses incurred during discharge represent an additional parasitic power requirement, however.

\subsubsection{Extraction Steam Subsystem}

This subsystem transports low-pressure steam extracted from the turbine to the chemical reactor subsystem during the discharge cycle. Design and performance characteristics are summarized in Table 4.3. Even at a design velocity of $45 \mathrm{~m} / \mathrm{sec}$ rather large-diameter piping would be required, although the minimal pressure drop calculated would suggest that a higher design velocity might be reasonable.

TABLE 4.2. HTF Subsystem Design and Performance

\begin{tabular}{|c|c|c|c|c|}
\hline \multirow[b]{2}{*}{ Variable } & \multicolumn{2}{|c|}{ Design 1} & \multicolumn{2}{|c|}{ Design 2} \\
\hline & Warm Line & Hot Line & Warm Line & Hot Line \\
\hline HTF temperature, ${ }^{\circ} \mathrm{C}$ & 304 & 391 & 265 & 350 \\
\hline Pipe diameter, m & 0.71 & 0.76 & 0.71 & 0.76 \\
\hline Flow rate, $\mathrm{kg} / \mathrm{sec}$ & 1100 & 1100 & 1170 & 1170 \\
\hline Pump power, kW & 480 & 80 & 500 & 90 \\
\hline
\end{tabular}


TABLE 4.3. Extraction Steam Subsystem Design and Performance

\begin{tabular}{|c|c|c|c|c|}
\hline $\begin{array}{c}\text { Extraction } \\
\text { Pressure, } \\
\text { kPa } \\
\end{array}$ & $\begin{array}{c}\text { Lost Power } \\
\text { Production, } \\
\mathrm{kW} \\
\end{array}$ & $\begin{array}{c}\text { Mass Flow } \\
\text { Rate, } \\
\mathrm{kg} / \mathrm{hr} \\
\end{array}$ & $\begin{array}{c}\text { Pipe } \\
\text { Diameter, } \\
\mathrm{m} \\
\end{array}$ & $\begin{array}{c}\text { Pressure } \\
\text { Loss in Pipe, } \\
\text { kPa }\end{array}$ \\
\hline 20.7 & 5000 & 161 & 2.3 & 0.76 \\
\hline 27.6 & 6350 & 159 & 2.6 & 0.62 \\
\hline 34.5 & 7460 & 158 & 3.0 & 0.48 \\
\hline
\end{tabular}

Steam cycle power losses associated with extracting low-pressure steam were calculated though application of the first and second laws of thermodynamics. The ideal turbine work produced per unit mass of steam was calculated based on isentropic expansion. Actual work produced per unit mass of steam was calculated based on a turbine efficiency of $85 \%$. The difference between the actual work produced at full expansion and that produced for expansion to $2 n .7,27.6$, or $34.5 \mathrm{kPa}(3,4$, or $5 \mathrm{psia})$ is the loss per unit mass of steam extracted. The total loss is simply the loss per unit mass multiplied by the steam rate required for discharge.

Luz is currently developing dry-cooled SEGS plant designs with turbine condensing pressures of $20.7 \mathrm{kPa}(3 \mathrm{psia})$ and higher. A dry-cooled power plant operating at these conditions would considerably enhance the projected performance of the storage system by reducing the amount of electricity production forgone by extracting low-pressure steam. Relative to the results presented in Table 4.3, which are based on wet-cooled steam cycle conditions, forgone power production would be reduced by $5 \mathrm{MW}$ if the average condensing pressure during discharge was $20.7 \mathrm{kPa}$ (3 psia).

\subsubsection{Chemical Reactor Subsystem}

The chemical reactor subsystem is the heart of the chemical reaction energy storage system. All other subsystems interact with the chemical reactor during charge and/or discharge cycles. Key elements of the reactor are a reactr. $r$ heat exchanger (proprietary property of Rocky Research), desuperheating and condensing tubing, and the reactor vessel. 
Reactor heat exchanger size, metal oxide ( $\mathrm{CaO})$ mass, and reactor vessel volume were scaled from design information provided by Dr. Uwe Rockenfeller of Rocky Research. Based on a net discharge capacity of 925 MWht, steam superheating losses on discharge of $9 \%$ (discussed below), and an $80 \%$ $\mathrm{CaO} / \mathrm{Ca}(\mathrm{OH})_{2}$ storage-medium utilization factor, the reactor was sized for a gross theoretical storage capacity of 1271 MWht. Key design factors specified by Or. Rockenfeller and the resultant design specifications are shown in Table 4.4.

Heat transfer surface area is required to desuperheat and condense steam leaving the reactor storage medium during the charging cycle. Cooling water was assumed to absorb the condensing energy first, followed by the desuperheating energy in a counterflow series arrangement. Parallel flow to desuperheating and condensing sections was also considered, but offered no significant performance advantage. Cooling water return temperatures were set to achieve log-mean temperature differences of approximately $1.4^{\circ} \mathrm{C}\left(2.5^{\circ} \mathrm{F}\right)$ and $2.8^{\circ} \mathrm{C}\left(5^{\circ} \mathrm{F}\right)$ when condensing at $29^{\circ} \mathrm{C}\left(85^{\circ} \mathrm{F}\right)$ and approximately $2.8^{\circ} \mathrm{C}\left(5^{\circ} \mathrm{F}\right)$ and $5.6^{\circ} \mathrm{C}\left(10^{\circ} \mathrm{F}\right)$ when condensing at $35^{\circ} \mathrm{C}\left(95^{\circ} \mathrm{F}\right)$. Overall heat transfer coefficients were assumed to be $313 \mathrm{~W} /\left(\mathrm{m}^{2}{ }^{\circ} \mathrm{C}\right)\left[55 \mathrm{Btu} /\left(\mathrm{hr} \mathrm{ft}^{2}{ }^{\circ} \mathrm{F}\right)\right]$ in the desuperheating section (Peters and Timmerhaus 1980; Perry and Green 1984) and

TABLE 4.4. Chemical Reactor Design Factors and Specifications Design Factors

$1.95 \mathrm{MJ} / \mathrm{kg} \mathrm{CaO}$

$0.11 \mathrm{~m}^{2}$ reactor heat exchanger surface/kg CaO

$19.2 \mathrm{l} / \mathrm{m}^{2}$ reactor heat exchanger surface

$50 \%$ reactor heat exchanger packing density (a)
Design Specifications

$2,346,000 \mathrm{~kg} \mathrm{CaO}$

$258,115 \mathrm{~m}^{2}$ reactor heat exchanger surface

$9,930 \mathrm{~m}^{3}$ vessel

(a) Modified from $70 \%$ packing density suggested by Dr. Rockenfeller to allow for desuperheating and condenser tubing. 
$3240 \mathrm{~W} /\left(\mathrm{m}^{2}{ }^{\circ} \mathrm{C}\right)\left[570 \mathrm{Btu} /\left(\mathrm{hr} \mathrm{ft}^{2}{ }^{\circ} \mathrm{F}\right)\right]$ in the condensing section (Sorensen 1983). The alternative design conditions and corresponding desuperheater and condenser heat transfer areas are summarized in Table 4.5.

During discharge, extraction steam is superheated to the average storagemedium temperature as it combines with calcium oxide to form calcium hydroxide. Part of the heat of reaction is consumed to provide the superheating energy, resulting in a loss of energy that would otherwise be available for heating the HTF. The fraction of the heat of reaction energy consumed for superheating varies slightly depending on extraction steam pressure and HTF discharge temperature. Higher HTF discharge temperatures require higher average storage-medium temperatures, hence greater superheating of the discharge steam. Higher extraction steam pressures have greater entering enthalpy and require less superheating energy. Superheating losses are specified in Table 4.6 for several combinations of extraction steam pressure and HTF discharge temperature.

\subsubsection{Other System Performance Impacts}

Discharging HTF from the reactor at $350^{\circ} \mathrm{C}\left(662^{\circ} \mathrm{F}\right)$ rather than $391^{\circ} \mathrm{C}$ $\left(735^{\circ} \mathrm{F}\right)$ results in derated steam conditions at the turbine inlet and poorer turbine cycle performarice relative to normal steam inlet conditions. The analysis assumed the steam pressure was the same as the standard plant with the steam temperature reduced by $41^{\circ} \mathrm{C}\left(73^{\circ} \mathrm{F}\right)\left[391^{\circ} \mathrm{C}\left(735^{\circ} \mathrm{F}\right)-350^{\circ} \mathrm{C}\left(662^{\circ} \mathrm{F}\right)\right]$, i.e., the HTF/steam approach temperature remained constant. Inlet steam was

TABLE 4.5. Desuperheating and Condenser Tubing Designs

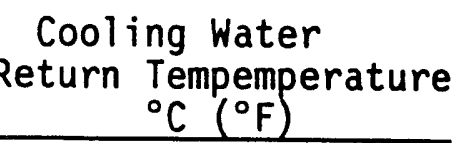

$28(82)$

$30(86)$

$33(92)$

$37(98)$

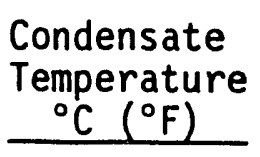

$29(85)$

$29(85)$

$35(95)$

$35(95)$
Desuperheater Area $\mathrm{m}^{2}\left(\mathrm{ft}^{2}\right)$

$690 \quad(7,430)$

$957(10,300)$

$646 \quad(6,950)$

$913 \quad(9,830)$

\section{Condenser Area} $\mathrm{m}^{2}\left(\mathrm{ft}^{2}\right)$

$5,451 \quad(58,670)$

$11,143 \quad(119,935)$

$2,730 \quad(29,380)$

$5,173 \quad(55,685)$ 
TABLE 4.6. Steam Superheat ing Losses

Extraction Steam

Pressure, $\mathrm{kPa}$

20.7

27.6

34.5

HTF Discharge Temperature
$\frac{391^{\circ} \mathrm{C}\left(735^{\circ} \mathrm{F}\right)}{350^{\circ} \mathrm{C}\left(662^{\circ} \mathrm{F}\right)}$

0.085

0.083

0.081 (a) Fraction of heat of reaction energy consumed for
superheating steam.

assumed to expand to the same conditions as the standard plant in the highpressure section of the turbine, but would only be reheated to the initial derated inlet temperature. The steam would then expand to the standard plant condenser conditions. The results of the analysis indicated that the derated inlet steam temperature would result in a $5.82 \%$ reduction in shaft power output per unit mass of inlet steam, assuming the turbine efficiency was $85 \%$ for both normal and derated conditions.

With or without storage, HTF is heated to $391^{\circ} \mathrm{C}\left(735^{\circ} \mathrm{F}\right)$ in the collector field. However, with storage, HTF is returned to the collector field at $315^{\circ} \mathrm{C}\left(599^{\circ} \mathrm{F}\right)$ rather than the normal $304^{\circ} \mathrm{C}\left(579^{\circ} \mathrm{F}\right)$. The resulting reduction in the change in enthalpy per unit mass of HTF delivered to storage requires a $14 \%$ increase in mass flow rate to maintain the same thermal power rating. Thus, collector field pumping power would be at least $14 \%$ greater than the normal $3000-\mathrm{kW}$ load, or an additional $420 \mathrm{~kW}$. The actual increase in field pumping power would almost certainly be higher if the effect of additional head losses through the collector piping system were included. (The latter was not calculated because collector tubing and field piping designs were not available and a higher HTF flow rate might also be accommodated by an alternative design.)

\subsection{COST ANALYSIS}

The total capital investments for alternative chemical reaction energy storage systems were calculated by aggregating estimates for individual system components. Included in the estimates are the costs associated with purchased 
equipment, direct construction labor and materials, indirect construction labor and materials, and construction contingency. The analys is assumed that standard unit costs would apply for individual components. No special allowance was included for additional costs that might be associated with the first system of this type constructed. Consistent with this estimating basis, contingency was set at $10 \%$ of purchased equipment plus direct and indirect materials and labor; a higher contingency rate would be justified for the first unit built.

Component estimates were developed using a "factored" estimating approach. Purchased equipment costs were estimated based on the design characteristics previously specified. Data sources included vendor quotes, estimating manuals, published articles, and previous project experience. Direct and indirect construction costs were estimated by multiplying purchased equipment costs by factors specific to each equipment type (Klumpar 1990; Guthrie 1974). A $10 \%$ contingency was added to the purchased equipment and construction cost subtotal to arrive at the total capital investment. Cost data were adjusted to reflect 1990 price levels.

Cooling subsystem cost estimates, shown in Table 4.7, were prepared for four alternative cooling water return temperatures. As expected, piping and pump costs decline significartly as the cooling water return temperature increases because of the decreased flow rate in these circumstances. Cooling tower costs follow the same trend, but are not quite as sensitive to flow rate as the piping and pumps.

TABLE 4.7. Cooling Subsystem Costs (thousands of $1990 \$$ )

\begin{tabular}{lcccc} 
& \multicolumn{4}{c}{ Cooling Water Return Temperature } \\
\cline { 3 - 6 } \multicolumn{1}{c}{ Component } & $\frac{28^{\circ} \mathrm{C}\left(82^{\circ} \mathrm{F}\right)}{300}$ & $\frac{30^{\circ} \mathrm{C}\left(86^{\circ} \mathrm{F}\right)}{1800}$ & $\frac{33^{\circ} \mathrm{C}\left(92^{\circ} \mathrm{F}\right)}{37^{\circ} \mathrm{C}\left(98^{\circ} \mathrm{F}\right)}$ & $\frac{1300}{1100}$ \\
\hline Piping and pumps & 2300 & 1800 & 1500 & 1300 \\
Cooling tower & 1900 & 3600 & 2800 & 2400
\end{tabular}


Condensate subsystem cost estimates, shown in Table 4.8, include charging and discharging piping loops, water treatment, and water storage. The low condensate flow rate results in trivial piping and pump costs compared to other subsystems. Water treatment costs are speculative because of uncertainties in treatment requirements.

The HTF subsystem consists of the supply and return piping connecting the collector field main and steam generator with the chemical reactor subsystem. Head losses through the piping subsystem are expected to be met by the collector field pumps, so no additional pumping equipment or capital cost is required. The total cost for the HTF piping subsystem was estimated to be $\$ 1,400,000$.

Extraction steam subsystem costs, shown in Table 4.9, were estimated for each of the three extraction pressures investigated in this study. The extraction steam subsystem consists of piping that connects the steam turbine with the chemical reactor. As would be expected, the extraction steam subsystem costs decline as the extraction pressure increases and the piping diameter decreases.

Estimated costs for the chemical reactor subsystem, shown in Table 4.10, are much greater than for any other subsystem. In fact, approximately $70 \%$ of the total estimated cost for the chemical reaction energy storage system is associated with the proprietary reactor heat exchanger and chemicals alone. Purchased equipment costs for these two items were based on vendor quotes

TABLE 4.8. Condensate Subsystem Costs (thousands of $1990 \$$ )

\begin{tabular}{lr}
\multicolumn{1}{c}{ Component } & Cost \\
\hline Piping and pumps & 90 \\
Water storage & 120 \\
Water treatment & $\underline{600}$ \\
Total & 810
\end{tabular}


TABLE 4.9. Extraction Steam Subsystem Costs (thousands 8 ? $1990 \$$ )

Extraction Pressure, $\mathrm{kPa}$

20.7

27.6

34.5 $\underline{\text { Cost }}$

1,600

1,400

1,200

TABLE 4.10. Chemical Reactor Subsystem Costs (thousands of $1990 \$$ )

Component

\begin{tabular}{lr}
\multicolumn{1}{c}{ Component } & Cost \\
\hline Reactor heat exchanger & 28,640 \\
Calcium oxide & 350 \\
Calcium oxide handling & 2,510 \\
Reactor vessel & 1,970 \\
Subtotal & 33,470
\end{tabular}

$\frac{\text { Desuperheating/Condensing Tubing }}{(\text { thousands }}$ (thousands of 1990 \$)

Cooling Water

Return Temperature ${ }^{\circ} \mathrm{C}\left({ }^{\circ} \mathrm{F}\right)$

$28(82)$

$30(86)$

33 (92)

37 (98)
Log Mean

Temperature Difference

${ }^{\circ} \mathrm{C}\left({ }^{\circ} \mathrm{F}\right)$

$2.8(5.0)$

$1.4(2.5)$

$5.6(10.0)$

$2.8(5.0)$ $\underline{\text { Cost }}$

1,900

3,500

1,100

1,900

received by Dr. Uwe Rockenfeller of Rocky Research. Using the procedure described above, an industry standard factor for heat exchangers was multiplied by the reactor heat exchanger purchased material cost to estimate direct and indirect construction material and labor costs. Calcium oxide material and handling costs were also based directly on figures provided by Dr. Rockenfeller. Costs for the reactor vessel and desuperheating/ condensing tubing were estimated as described at the beginning of this section. 
Desuperheating and condensing tubing costs were evaluated for the four alternative cooling water return temperatures considered. Tubing costs are proportional to the underlying heat transfer area and log-mean temperature difference between the cooling water and vapor/condensate.

It should be noted that considerable uncertainty is associated with the cost estimate for the chemical reactor subsystem because of its early stage of development. Hence, there is considerable uncertainty associated with the cost estimate for the entire storage system. 


\subsection{SYSTEM RESULTS}

Subsystem cost and parasitic power requirements are summarized in Tables 5.1 and 5.2. Examination of the data in the two tables identifies some system configurations as being clearly inferior, while most of the system configurations fall into an indeterminate category, not clearly being inferior or superior. Inferior configurations are those with greater parasitic power for the same or greater cost or greater cost for the same or greater parasitic power. Configurations with lower parasitic power, but greater cost or greater parasitic power, but lower cost fall into the indeterminate category. The result is several viable systems with alternative combinations of initial capital cost and parasitic power. A full annual system simulation of the solar thermal power plant, which was beyond the scope of this study, would have to be conducted to properly determine tradeoffs in cost and parasitic power.

Two alternative cooling water return temperatures were investigated for each of the two condensation temperatures considered during the charging cycle. Cooling system and desuperheating/condensing tubing costs, and cooling system fan and pump parasitic power are affected by these alternative design conditions. The results presented in Tables 5.1 and 5.2 show that the higher condensation temperature $\left[35^{\circ} \mathrm{C}\left(95^{\circ} \mathrm{F}\right)\right]$ would be preferred because of its lower cost and reduced parasitic power, but the vapor pressure driving force is only half that available for the lower condensation temperature $\left[29^{\circ} \mathrm{C}\left(85^{\circ} \mathrm{F}\right)\right]$. For a given condensation temperature, the higher cooling water flow results in a more expensive system, but with reduced parasitic power. Thus, any of the four combinations of condensation temperature and cooling water return temperature might be preferred.

Extraction steam pressures of $20.7,27.6$, and $34.5 \mathrm{kPa}(3,4$, and $5 \mathrm{psia})$ were considered for discharge. Pressures of 20.7 and $27.6 \mathrm{kPa}$ ( 3 and $4 \mathrm{psia}$ ) are applicable to discharging $350^{\circ} \mathrm{C}\left(662^{\circ} \mathrm{F}\right)$ HTF from storage while 27.6 and $34.5 \mathrm{kPa}$ ( 4 and $5 \mathrm{psia}$ ) pressures result in identical vapor pressure driving forces for discharging $H T F$ at $391^{\circ} \mathrm{C}\left(735^{\circ} \mathrm{F}\right)$. Again, none of the alternative extraction pressures is ciearly inferior or superior. As the extraction pressure is increased, the cost of the steam piping declines and the vapor 
TABLE 5.1. System cost Summary

Subsystem

Initial Capital Cost, Millions of $1990 \$$

Cooling

$29^{\circ} \mathrm{C}$ condensate

$28^{\circ} \mathrm{C}$ cooling water return

4.2

$30^{\circ} \mathrm{C}$ cooling water return

3.6

$35^{\circ} \mathrm{C}$ condensate

$33^{\circ} \mathrm{C}$ cooling water return

2.8

$37^{\circ} \mathrm{C}$ cooling water return

2.4

Condensate

0.8

HTF

1.4

Extraction steam

$20.7 \mathrm{kPa}$

1.6

$27.6 \mathrm{kPa}$

1.4

$34.5 \mathrm{kPa}$

1.2

Chemical reactor

reactor heat exchanger, chemicals, chemical handling, reactor vessel

33.5

desuperheating/condensate tubing

$29^{\circ} \mathrm{C}$ condensate

$28^{\circ} \mathrm{C}$ cooling water return

1.9

$30^{\circ} \mathrm{C}$ cooling water return $\quad 3.5$

$35^{\circ} \mathrm{C}$ condensate

$33^{\circ} \mathrm{C}$ cooling water return

1.1

$37^{\circ} \mathrm{C}$ cooling water return

1.9

pressure driving force increases, but power.production from the turbine also decreases.

Discharging $\mathrm{HTF}$ at $391^{\circ} \mathrm{C}\left(735^{\circ} \mathrm{F}\right)$ rather than $350^{\circ} \mathrm{C}\left(662^{\circ} \mathrm{F}\right)$ is clearly a superior design condition. The higher discharge temperature requires a 6.9 $\mathrm{kPa}$ ( 1 psia) increase in extraction steam pressure. The increased power output associated with the higher HTF temperature (and resultant higher inlet steam temperature) more than compensates for the additional power losses resulting 
TABLE 5.2. System Parasitic Power Summary

Subsystem

Parasitic Power, kW(a)

Cooling

$29^{\circ} \mathrm{C}$ condensate

$28^{\circ} \mathrm{C}$ cooling water return $\quad 1870$

$30^{\circ} \mathrm{C}$ cooling water return $\quad 1420$

$35^{\circ} \mathrm{C}$ condensate

$33^{\circ} \mathrm{C}$ cooling water return $\quad 1250$

$37^{\circ} \mathrm{C}$ cooling water return $\quad 1190$

Condensate

10

HTF

charging

0

discharging

550

Extraction steam

$20.7 \mathrm{kPa}$

5000

$27.6 \mathrm{kPa}$

6400

$34.5 \mathrm{kPa}$

7400

Chemical reactor

8600

HTF discharge temperature

$391^{\circ} \mathrm{C}$

$350^{\circ} \mathrm{C}$

0

5100

Solar field

420

(a) Represents either additional electric power consumed
or electric power production foregone.

from extracting steam at a higher pressure. An additional benefit is the reduced cost of the higher pressure steam piping.

Eight unique combinations of initial capital cost, parasitic power requirement, and vapor pressure driving forces can be assembled from the subsystem design alternatives considered, none of which is clearly inferior or superior. System characteristics are summarized in Table 5.3. The second-law efficiencies of the systems represent the ratio of net electric energy production potential of storage discharging energy compared to the gross 
TABLE 5.3. Sumnary of System Characteristics

System Description

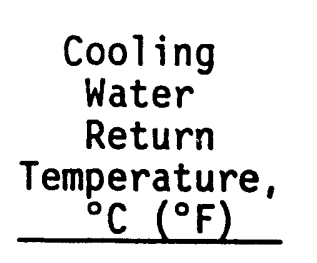

28 (82)

$30(86)$

$33(92)$

37 (98)

$28(82)$

$30(86)$

$33(92)$

37 (98)

\section{Extraction Initial}

Steam Cost,

Pressure, 1990 \$/

$\mathrm{KPa}$

27.6

27.6

27.6

27.6

34.5

34.5

34.5

34.5
kWht

46.7

47.8

44.3

44.8

46.5

47.6

44.1

44.5

\section{System Characteristics}

\begin{tabular}{c} 
Second-Law \\
Efficiency, \\
$\frac{\%}{\%}$ \\
\hline
\end{tabular}

78.9

79.9

80.2

80.4

77.9

78.8

79.2

79.3
Vapor Pressure

Driving Force, $\mathrm{kPa}$

Charge Discharge

2.9

7.3

2.9

7.3

1.4

7.3

1.4

7.3

2.9

14.3

2.9

14.3

1.4

14.3

1.4

14.3

electric energy production potential of storage charging energy. The difference between charge and discharge electric energy production potential is equal to the sum of parasitic power consumption occurring during the 8-hour charging and 4-hour discharging periods.

A review of the data presented in Table 5.3 indicates that the least expensive system has an initial capital cost equivalent to $\$ 44.1 / \mathrm{kWh}$ and a second-law efficiency of $79.2 \%$. The most efficient system $(80.4 \%$ ) has an initial capital cost of $\$ 44.8 / \mathrm{kWht}$. Second-law efficiencies near $85 \%$ would be possible if dry-cooled SEGS plant designs being developed by Luz are implemented. Although none of the systems evaluated were estimated to meet Luz International's stated cost goal of $\$ 25 / \mathrm{kWht}$, the following factors need to be considered.

1. Mass production of the reactor heat exchanger surface area, the largest system cost component, could significantly reduce the overall system
cost.

2. The actual allowable cost varies depending on storage system efficiency as well as the characteristics of a solar thermal power plant and the value of the power it produces. 


\subsection{CONCLUSIONS AND RECOMMENDATIONS}

The principal conclusion of this study is that chemical reaction energy storage based on the reversible reaction $\mathrm{CaO}+\mathrm{H}_{2} \mathrm{O}=\mathrm{Ca}(\mathrm{OH})_{2}$ could be technically and economically feasible at a SEGS solar thermal power plant. Second-law efficiencies near $80 \%$ and initial costs of about $\$ 45 / \mathrm{kWh}$ were predicted for several alternative design configurations incorporating wetcooling. Second-law efficiencies near $85 \%$ would be possible if dry-cooled SEGS plant designs being developed by Luz International are implemented. Although the capital cost estimate exceeds Luz International's stated requirement of $\$ 25 / \mathrm{kWht}$, ancillary subsystems (cooling, condensate, HTF, and extraction steam) were found to represent less than $20 \%$ of the total system cost and significant cost reductions could be realized through mass production and further optimization of the expensive reactor heat exchanger system components. However, the following major technical and economic questions must be resolved:

1. How much will mass production and/or further optimization reduce the cost of the reactor heat exchanger system?

2. Will the temperature and vapor pressure driving forces available allow timely charge and discharge rates?

3. How will desuperheating/condensing tubing and the reactor heat exchanger surface be integrated to obtain uniform bulk condensing conditions at the close cooling water approach temperatures required?

Other concerns include valving and piping design details for the steam extraction line and potential corrosion problems associated with the caustic nature of calcium oxide and calcium hydroxide.

Whether or not this particular reversible reaction proves feasible for application at the SEGS power plants, the general concept has considerable potential for high-temperature energy storage and heat-pump applications. Recommendations for immediate future work are as follows:

1. Other reversible oxide/hydroxide reaction pairs should be investigated as possible chemical reaction energy storage media. The investigation should focus on determining the vapor pressure of water over the 
oxide/hydroxide storage medium as a function of temperature. Large differences between the vapor pressure of water over the oxide/hydroxide storage medium and the vapor pressure of pure water provides the basis for constructing an energy storage system based on reversible reactions of this type. Further study is warranted to confirm previous experimental data collected for calcium oxide/calcium hydroxide and other metal oxide/metal hydroxide systems.

2. Other potential applications of oxide/hydroxide energy storage systems should be identified. Any situation with a periodic high-temperature energy source and a low-grade waste heat source could potentially apply this concept.

3. The mass transfer, heat transfer, and chemical reaction dynamics of the calcium oxide/hydroxide system should be investigated to determine the required pressure and temperature gradients for modified reactor designs.

4. Reactor heat exchanger manufacturing costs for utility-scale storage systems should be estimated.

5. The potential benefit of boosting the discharge HTF temperature above that normally delivered, thus allowing higher inlet steam temperatures and improved steam cycle conversion efficiency, should be investigated.

Subsequent to completing these five activities, two additional activities are recommended:

1. The impact of direct steam generation in the solar field and dry-cooling, two design changes currently being investigated by Luz for future SEGS plants, should be evaluated in more detail.

2. An hour-by-hour annual simulation of SEGS plant performance should be conducted for alternative field sizes and storage system sizes to determine the optimum use of storage. 


\subsection{REFERENCES}

Crane Company. 1979. Flow of Fluids Through Valves, Fittings, and Pipe. New York.

Guthrie, K. M. 1974. Process Plant Estimating, Evaluation, and Control. Craftsman Book Company, Solana Beach, California.

Klumpar, I. V. 1990. "Upgrading Capital Estimation Factors and Correlations." In 1990 AACE Transactions. American Association of Cost Engineers, Morgantown, West Virginia.

Luz International. 1989. Phase Change Thermal Energy Storage. SERI/STR-2503516, Prepared by Luz International, Los Angeles, California for Solar Energy Research Institute, Golden, Colorado.

Peters, M. S., arid K. D. Timmerhaus. 1980. Plant Design and Economics for Chemical Engineers. McGraw-Hill Book Company, New York.

Perry, R. H., and D. W. Green. 1984. Perry's Chemical Engineers' Handbook. McGraw-Hill Book Company, New York.

Sorenson, H. A. 1983. Energy Conversion Systems. John Wiley and Sons, New York. 


\section{DISTRIBUTION}

No. of

Copies

\section{OFFSITE}

U.S. Department of Energy

Attn: R. Eaton

Office of Energy Management

Forrestal B1dg, CE-142 5E-036

Washington, DC 20585

U.S. Department of Energy

Attn: K. Klunder

Office of Energy Management

Forrestal B1dg, CE-142 5E-036

Washington, DC 20585

U.S. Department of Energy

Attn: E. Reimers

Office of Energy Management

Forrestal Bldg, CE-142 5E-036

Washington, DC 20585

12 DOE/Office of Scientific and

Technical Information

Electric Power Research Institute

Attn: V. Rabl

PO Box 10412

Palo Alto, CA 94303

Electric Power Research Institute

Attn: R. Wendland

PO Box 10412

Palo Alto, CA 94303

Energetics, Inc.

Attn: Jon Hurwitch

7164 Gateway Drive

Columbia, MD 21046

Institute of Gas Technology

Attn: J. O'Sullivan

3424 S. State

Chicago, IL 60612
No. of

Copies

Jaehne \& Associates

Attn: H. Jaehne

1901 Emerson Avenue S.

Suite 105

Minneapolis, MN 55403

J. L. LaMarche

South 511 Sullivan St.

Apt. 310

Verdale, WA 99037

Luz International

Attn: D. Kearney

924 Westwood Blvd.

Los Angeles, CA 90024

Charles F. Meyer

1141 Cima Linda Lane

Santa Barbara, CA 93108

National Aeronautics and Space Administration

Asst. Adm. for Energy Programs

Washington, DC 20585

New York State Energy

Research \& Development Agency

Attn: G. Walmet

Rockefeller Plaza

Albany, NY 12223

Oak Ridge National Laboratory

Attn: J. Tomlinson

Building 9204-1, MS 8045

Y-12 Plant, Box 2009

Oak Ridge, TN 37831-8045

Office of Congressman

Sid Morrison

1330 Longworth Bldg.

Washington, DC 20515 
No. of

Copies

Office of Congressman

Tom Bevil

2302 Rayburn B1dg.

Washington, DC 20515

Resource Efficiency, Inc.

Attn: M. Spurr

340 Daly Street

St. Paul, MN 55102

5 Rocky Research

Attn: U. Rockenfeller

674 Wells Road

PO Box 1086

Boulder City, NV 89005

Sandia National Laboratories

Technical Library

Division 3141

Albuquerque, NM 87185

Sandia National Laboratories

Attn: C. Tyner

Division 6216

Albuquerque, NM 87185

Solar Energy Research Institute

Attn: B. Gupta

1536 Cole Blvd.

Golden, CO 80401

Southern Company Services, Inc.

Attn: K. Vakhshoorzadeh

PO Box 2625

Birmingham, AL 35202

University of Alabama

Attn: E. Brett

School of Mines and Energy Development

Box 870164

Tuscaloosa, AL 35487-0164

University of Massachusetts at Amherst

Attn: D. Breger

Dept. of Mechanical Eng.

Eng. Laboratory Bldg.

Amherst, MA 01003
No. of

Copies

University of Massachusetts

at Amherst

Attn: J. E. Sunderland

Dept. of Mechanical Eng.

Eng. Laboratory Bldg.

Amherst, MA 01003

US Army Corps of Engineers

Attn: C. W. Sohn

Construction Engineering

Research Laboratory

PO Box 4005

Champaign, IL 61820-1305

US Department of Interior

Attn: Natural Resources Library

Serials Branch (G/E)

Washington, DC 20240

\section{FOREIGN}

Bengt Hidemark Gosta Danielson Arkitekter SAR

Attn: A. Boysen

Jarntorget 78

S-11 29 Stockholm

Sweden

Commission of European

Communities

Attn: P. Zegers

DG XII, E3

200 Weststraat

Brussels, Belgium

DFVLR

Attn: M. Becker

Bereich Projekttragerschaften

Linder Hohe

5000 Koeln 90

Germany

DIDIER Werke

Attn: C. Streuber

Lessingstrasse 16-18

D-6200 Wiesbaden 1

Germany 
PNL-7799

UC-202

No. of

Copies

Helsinki University of Technology

Attn: P. Lund

Otakaari 3

SF-02150 Espoo

Finland

I.E.N.E.R.

EPF-Ecublens

Attn: B. Saugy

1015 Lausanne

Switzerland

IF Technology

Attn: A. Snijders

Fronbregstraat 1

6814 RE Arnhem

The Netherlands

\section{Institut Fisica Universite \\ Attn: F. Reale \\ P. le Tecchio \\ 80125 Napoli \\ Italy \\ Institut fur Kernenergetik und Energiesystems \\ Attn: M. Groll \\ Universitat Stuttgart \\ Pfaffenwaldring 31 \\ Postfach 801140 \\ 7000 Stuttgart 80 \\ Germany}

Institut fur Thermodynamik and Waermetechnik

Attn: U. Gross

Universitat Stuttgart

Pfaffenwaldring 6

7000 Stuttgart 80

Germany
No. of

Copies

KFA Julich

Projektleitung Energieforschung

Attn: F.J. Friedrich

PO Box 1913

D-5170 Julich

Germany

KFA Julich, PLE

Attn: V. Lottner

PO Box 1913

D-5170 Julich

Germany

KM Kjessler \& Mannerstrale $A B$

Attn: S. Lundin

PO Box 7124

S-171 07 Solna

Sweden

Laboratory for Energetics

Attn: B. Qvale

Technical University of Denmark DTH Building 403

DK-2800 Lyngby

Denmark

Lambrecht Industrial Consultants

Attn: J. Lambrecht

Max-Ruttgers-Str 29

D-8021 Irschenhausen

Germany

B. Matthey

Consulting-Engineers Ltd.

CH-2205 Montezillon-Neuchatel

Switzerland

Ministry of Trade and Industry

Attn: Pirjo-Liisa Vainio

Acting Head of R\&D Div.

Energy Department

Pohjoinen Makas i ininkatu 6

00130 Helsinki

Finland 
No. of

\section{Copies}

NOVEM

Attn: G. J. van Mourik

PO Box 8242

Leidseveer 35

3503 RE Utrecht

The Netherlands

Public Works Canada

Attn: E. L. Morofsky

C456 Sir Charles Tupper Bldg.

Riverside $\mathrm{Dr}$. and Heron Rd.

Ottawa, Ontario

K1A OM2 Canada

Riso National Laboratory

Attn: P. L. Christensen

DK-4000 Roskilde

Denmark

Swedish Council for Building Research

Attn: W. Raldow

St. Goransgatan 66

S-11233 Stockholm

Sweden

Swedish Council for Building Research

Attn: B. T. Sellberg

Sankt Goransgatan 66

S-11233 Stockholm

Sweden
No. of

Copies

$$
\begin{aligned}
& \text { Universitat Stuttgart } \\
& \text { Attn: Rudolf Giebe } \\
& \text { Pfaffenwaldring } 6 \\
& 7000 \text { Stuttgart } 80 \\
& \text { Germany }
\end{aligned}
$$

\section{ONSITE}

DOE Field Office, Richland

R. B. Goranson, A5-90

28 Pacific Northwest Laboratory

D. R. Brown, K6-61 (10)

M. K. Drost, K5-19

L. D. Kannberg K5-21 (10)

G. E. Spanner, K6-63

Publishing Coordination Technical Report Files (5) 

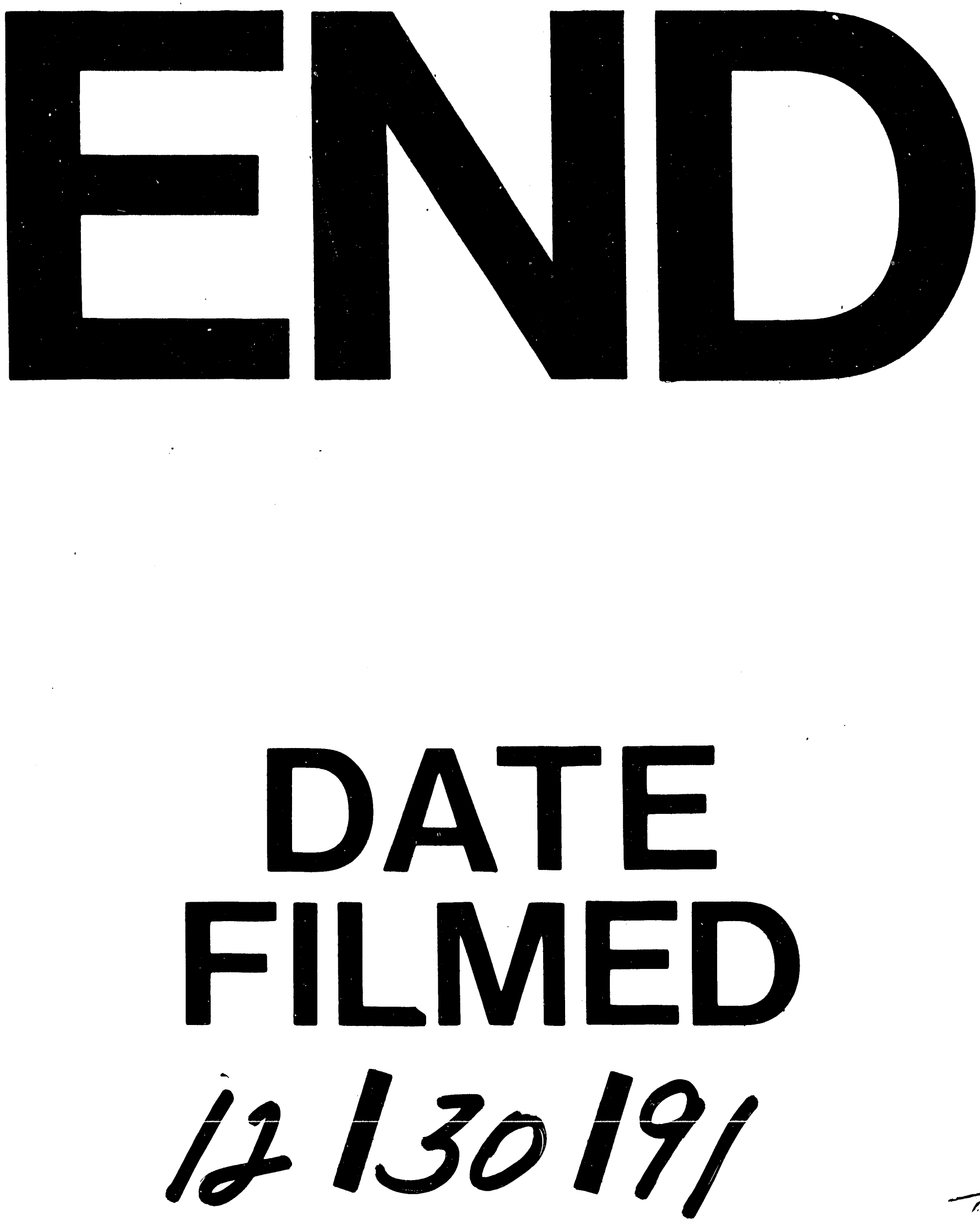
